NOTE TO USERS

This reproduction is the best copy available.

(B)

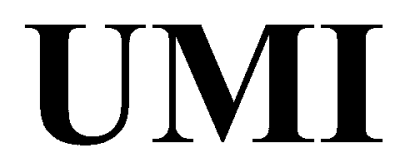





\title{
CANNABIS AND THE COURTS: \\ An examination of judicial responses to cannabis
}

\author{
By \\ André Zaria Solecki, B.A. \\ A thesis submitted to \\ the Faculty of Graduate Studies and Research \\ in partial fulfillment of \\ the requirements for the degree of \\ Master of Arts \\ Department of Sociology and Anthropology \\ Carleton University \\ Ottawa, Ontario \\ December $5^{\text {th }} 2007$
}




$\begin{array}{ll}\begin{array}{l}\text { Library and } \\ \text { Archives Canada }\end{array} & \begin{array}{l}\text { Bibliothèque et } \\ \text { Archives Canada }\end{array} \\ \begin{array}{l}\text { Published Heritage } \\ \text { Branch }\end{array} & \begin{array}{l}\text { Direction du } \\ \text { Patrimoine de l'édition }\end{array} \\ \begin{array}{l}\text { 395 Wellington Street } \\ \text { Ottawa ON K1A 0N4 } \\ \text { Canada }\end{array} & \begin{array}{l}\text { 395, rue Wellington } \\ \text { Ottawa ON K1A 0N4 } \\ \text { Canada }\end{array}\end{array}$

Your file Votre référence ISBN: 978-0-494-40613-7

Our file Notre référence

ISBN: 978-0-494-40613-7

NOTICE:

The author has granted a nonexclusive license allowing Library and Archives Canada to reproduce, publish, archive, preserve, conserve, communicate to the public by telecommunication or on the Internet, loan, distribute and sell theses worldwide, for commercial or noncommercial purposes, in microform, paper, electronic and/or any other formats.

The author retains copyright ownership and moral rights in this thesis. Neither the thesis nor substantial extracts from it may be printed or otherwise reproduced without the author's permission.
AVIS:

L'auteur a accordé une licence non exclusive permettant à la Bibliothèque et Archives Canada de reproduire, publier, archiver, sauvegarder, conserver, transmettre au public par télécommunication ou par l'Internet, prêter, distribuer et vendre des thèses partout dans le monde, à des fins commerciales ou autres, sur support microforme, papier, électronique et/ou autres formats.

L'auteur conserve la propriété du droit d'auteur et des droits moraux qui protège cette thèse. $\mathrm{Ni}$ la thèse ni des extraits substantiels de celle-ci ne doivent être imprimés ou autrement reproduits sans son autorisation.
In compliance with the Canadian Privacy Act some supporting forms may have been removed from this thesis.

While these forms may be included in the document page count, their removal does not represent any loss of content from the thesis.
Conformément à la loi canadienne sur la protection de la vie privée, quelques formulaires secondaires ont été enlevés de cette thèse.

Bien que ces formulaires aient inclus dans la pagination, il n'y aura aucun contenu manquant.

\section{Canada}




\begin{abstract}
Are sentences received for cannabis offences different than sentences given for other narcotics offences? Is cannabis responded to differently than for other drug crimes in Canada's courts? In the following research thesis, the researcher examines judicial sentencing responses, from variations in sentencing data to statements made in case-law, regarding cannabis offences, cannabis offenders, and the developed discourse regarding cannabis in Canada. The research finds that judicial sentencing practices with respect to cannabis and other narcotics are diverse, and that verbal responses to these cases from the bench are almost as varied as the positions taken in the cannabis debate. Ultimately, this thesis shows that judges do not respond uniformly nor routinely in the sentencing of cannabis offenders, regardless of the embedded law enforcement discourse or the sentencing maximums discussed in Parliament.
\end{abstract}




\section{Dedicated to}

My father, Samuel,

And my love, Erin. 


\section{TABLE OF CONTENTS}

Chapter 1: Introduction 1

Chapter 2: Theory 6

Chapter 3: Law Enforcement, Discretion, and the Judiciary 14

Chapter 4: The Cannabis Debate 34

$\begin{array}{ll}\text { Chapter 5: Methodology } & 47\end{array}$

$\begin{array}{ll}\text { Chapter 6: Findings } & 57\end{array}$

Chapter 7: Conclusions and Recommendations $\quad 83$

$\begin{array}{ll}\text { Appendices } & 88\end{array}$ 


\section{LIST OF TABLES}

TABLE 1: Distribution of all charges in index period 57

TABLE 2: Offence type counts by year of charge 59

TABLE 3: Cannabis charges by type of offence

TABLE 3.1: Not sentenced by type of narcotics offence 63

TABLE 4: Cannabis possession, general possession, and 65 disposition type

TABLE 5: Cannabis trafficking, general trafficking and disposition 68 type

TABLE 6: Cannabis production, general production and disposition

71 type

TABLE 7: Distribution of sentencing and judicial discretion themes 


\section{LIST OF APPENDICES}

$\begin{array}{ll}\text { APPENDIX I: BIBLIOGRAPHY } & 88\end{array}$

APPENDIX II: CANNABIS CASES DRAWN FROM LEXIS 96

NEXIS $(\mathbb{R}$

APPENDIX III: SERIOUSNESS RANKINGS 97

APPENDIX IV: FREQUENCY DISTRIBUTION OF 99

JURISDICTION IN CASE-LAW REVIES

APPENDIX V: SCHEDULES II, VII, AND VIII OF THE 100

CONTROLLED DRUGS AND SUBSTANCES $\mathrm{ACT}$ 


\section{CHAPTER 1: INTRODUCTION}

"Law and morality represent the totality of bonds that bind us to one another and to society, which shape the mass of individuals into a cohesive aggregate. We may say that what is moral is everything that is a source of solidarity, everything that forces man to take account of other people, to regulate his actions by something other than the promptings of his own egoism, and the more numerous and strong these ties are, the more solid is the morality" (Durkheim 1984, p.331)

There is a long tradition in the sociology of law that addresses the relationship that exists between moral values that are codified into laws and the consensus which exists in society over such laws. Tensions can arise when a law prohibits what many people consider moral and acceptable behaviour. Investigating these tensions provides insight into the dynamic processes involved in the creation and implementation of the law in society. Within this context, the way people and institutions respond to controversy or debate over a particular law provides a glimpse into the nature of the existing consensus over political and legal power. This thesis identifies cannabis and the laws pertaining to it as controversial and the debate over these laws provides such a glimpse into the consensus regarding legal power.

Cannabis use in Canada is an act which has been the subject of moral, legal, and social debate for nearly a century (Erickson 1980, Giffen et al. 1991, CBC 2007). In other words, it is a long-contested topic in Canadian society. The debate surrounding cannabis inevitably reflects a broader discussion related to how some laws are perceived in Canada. While the law defines cannabis use as illegal, many generations of Canadians have disagreed with this law and many more continue to disagree (Erickson 1980, Giffen et al. 1991, Kenny and Nolin 2003, Gardner 2007). It appears Canadians have mixed views on the legitimacy, or illegitimacy, of Canada's cannabis laws. 
Recently, Canada's highly visible cannabis debate was discussed in the United Nations, where it was noted that Canada was among the top cannabis using nations in the world (O'Neill 2007). The ongoing controversy over cannabis legislation presents a challenge both to those actors charged with the responsibility of creating the law as well as those individuals responsible for finding guilt and punishing cannabis offenders.

Indeed, the lack of consensus in the cannabis debate has important implications for Members of Parliament, the social groups either promoting or resisting change to cannabis laws, and representatives of the criminal justice system, most notably the judiciary. Each of these groups plays an important role in influencing laws pertaining to cannabis, though some groups have a more powerful influence than others. While politicians have the final say on what is and what is not law, other opinions and criticisms may emanate from Canada's legal institutions. For example, the response of the judiciary may be particularly important since judges, like the police, deal with those individuals who transgress cannabis laws. This thesis examines the sentencing practices pertaining to cannabis offences and cannabis offenders to see how judges have been responding to existing cannabis laws.

Responses to cannabis from the judiciary are neither as public nor as visible as those of others institutions and social groups. Research and information in this area are important since the judiciary is a key element involved in regulating and perpetuating a democratic and just society. This is noted since judges mediate between the power of the state and the rights of Canadians. While there has been research on the responses of other members of the criminal justice system, such as law enforcement, there is little focused research on the responses of the judiciary to cannabis in Canada. However, the little 
existing research indicates that differing judicial responses may exist and that examining sentencing is a suitable method to see if indeed they do (Macdonald et al. 1999, Macdonald and Erickson 1999). Hence, there is evidence to show that judicial responses differ on cannabis. This thesis contributes to this area of research by analysing sentencing trends and sentencing remarks made by Canadian judges to cannabis offenders.

In this study, we examined how one component of the criminal justice system, the judiciary, is responding to cannabis by looking at the sentences awarded to cannabis offenders. An important aspect of this research is to compare the sentences given to those convicted of various cannabis offences in Canadian courts with the sentences given to those convicted of comparable narcotics offences. Other narcotics offence sentences, involving drugs such as cocaine, heroin and methamphetamines, will be compared to those sentences given for similar cannabis offences. An important hypothesis suggests that if the debate over cannabis influences other sectors in Canadian society, members of the judiciary may be similarly affected and this may be reflected in the sentences they give as well as the rationales they offer for their sentencing decisions. Judges, due to their vocational restraints, rarely question the legitimacy of laws drafted in Parliament. However, their opinions may be visible as they discharge their professional duties; the sentences they hand down and the rationales they provide for them may indicate whether judges perceive cannabis as a social problem or as a harmless social phenomenon.

This thesis begins with an overview of the development of law as proposed by Emile Durkheim and modernized by contemporary social theorists. The theoretical approach adopted suggests that morality is a developed code of conduct designed to help societies regulate, perpetuate, and transform themselves. Morality is thus the impetus for 
the construction of law. Drawing on the Durkheimian tradition, this thesis uses functionalism to understand and explain how social actors construct and transform society through the concept of morality and collective consciousness. Utilizing this understanding of morality and law allows us to interpret perceptions of cannabis and cannabis legislation as dynamic and helps to situate the practices of those who judge cannabis law as necessarily dynamic. Judges are themselves a part of the broader social discourse and are, due to their social and legal status, capable of influencing how criminal phenomena are perceived.

Discussion regarding the implications of cannabis laws for actors in the criminal justice system follows the theory of the functional-moral development of law. First, the concept of discretion in law enforcement is examined with respect to cannabis, and this concept is linked to a similar practice in the judiciary. The concept of discretion is related to the judiciary to suggest that it might be possible for judges to have varying responses to laws, offences, and offenders. There are limits to this discretion, however, and they are addressed with reference to how they are encoded in criminal law, as well in the vocational obligations of being a judge in Canada. Further, a detailed examination of Canada's cannabis law is presented. It is essential to understand the context of the law and the limitations to judicial practices, prior to examining possible responses emanating from the judiciary, since it is these very laws which may shape, amplify and alter these responses.

The fourth chapter includes a discussion of the cannabis debate in Canada. It provides some social and political context to the debate, as well as discussing who contests the law and who wishes to see it reinforced. It is in this chapter that substantive 
evidence of a lack of consensus in Canada regarding cannabis is presented. Discussion here focuses on government publications concerning cannabis, medicinal cannabis campaigns, and arguments for and against cannabis liberalization. Understanding the various components of the debate will help us to understand the possible social, legal, and political influences felt by the judiciary when sentencing cannabis offenders.

Discussion of the research design and methodology used in this study follows the outline of the cannabis debate. The methodology consists of a mixed quantitative and qualitative approach including an analysis of aggregate statistics as well as case-based qualitative evidence. These are used to help understand the responses of the judiciary to cannabis violations, and to help understand what these responses might mean in the broader context of the cannabis debate. Limits and benefits of this approach are addressed, as well as comparisons to methods used in similar research.

The final chapters contain findings, conclusions and recommendations based on the research described above. These chapters present a discussion of the implications the findings have for policy, the judiciary and the legal system in general. Some suggestions are also made regarding further research. 


\section{CHAPTER 2: THEORY}

\section{The Functional Construction of Law Through Morality}

Mapping the development of law in society has long been the focus of sociological investigation. From Marxian analyses of how the law protects property and the means of production, to Emile Durkheim's structural-functional and organic theses, law has held a significant place in the study of society by classical theorists. Further, recent updating of classical theory provides insights into how social actors and institutions participate in the construction of society and law while still remaining critical of norms and socially regulative forms of conduct (Schmaus 2004, Ben-Yehuda 2006, Pridemore and Kim 2007). This challenges criticisms of classical theory which suggest that it is circuitous to examine and attempt an explanation of one's own social relations (Law 2004).

Though Durkheim's pure functionalism is a historically dated theory, modern sociological theorists such as the Israeli scholar Nachman Ben-Yehuda and the American Warren Schmaus have made it relevant for contemporary analysis. The functional perspective suggests that the social rules by which we live are constructed, maintained, and replaced by broad agreement among citizens regarding what is moral, what is legal, and what is harmful behaviour (Durkheim 1984, Schmaus 2004, Ben-Yehuda 2006). Further, as society collectively defines good behaviour and bad behaviour, the possibility for reinforcing and limiting our perceptions of what is acceptable and what is illegal behaviour becomes available. Our discussion begins with a brief interpretation of functional theory and is followed by an explanation of why it is suitable for this specific project. 
Functional theory, at its core, attempts a scientific explanation of society as though it were an organic entity. Durkheim's positivistic thesis suggested that human society, much like animals and plants in the 'natural world,' abides by socially produced forms of conduct which regulate human behaviour (Durkheim 1982). Humans, Durkheim suggested, develop a division of labour to sustain and proliferate the vastly complex civilizations of humanity:

Indeed, as the environment in which societies live becomes increasingly complex, and consequently more fluctuating, they must change frequently in order to survive. Furthermore, the more the consciousness remains unenlightened, the more averse it is to change, because it does not perceive rapidly enough either the need for change or the direction change should take (Durkheim 1984, p.14).

Durkheim suggests that less complex societies rely on mechanical solidarity to reinforce social norms and to regulate the behaviour of their constituents. These societies displaying mechanical solidarity are characterised by a high degree of homogeneity and the institutionalization of repressive law. Though the laws are punitive and harsh, Durkheim suggests that they do not appear so to social actors where mechanical solidarity is present since the laws are designed to protect the collective whole and reinforce a sense of community, belonging, and responsibility (Durkheim 1984, p.85).

As societies develop over time, Durkheim argues, the vastly complex organizations required to build and structure a large civilization transform the simple social relations in those social settings where mechanical solidarity existed. This transformation is spurred by the division of labour:

We can no longer be under any illusion about the trends in modern industry. It involves increasingly powerful mechanisms, large scale groupings of power and capital, and consequently an extreme division of labour. Inside factories, not only are jobs demarcated, becoming extremely 
specialised, but each product is itself a specialty entailing the existence of others (Durkheim 1984, p.1).

As social actors become more specialized and differentiated in their day to day lives, they display characteristics of a new form of solidarity: organic solidarity. Organic solidarity represents the weakening of less complex social relations and the creation of a variety of social relations pertaining to diverse social groups different in background, employment, and beliefs. In a society where the collective is composed of various differing opinions, attitudes and backgrounds, there is a possibility that the ties that bind the collective whole can be weakened. To prevent this weakening, Durkheim proposes that specialised law is required to elicit the consent of individuals for the maintenance of these diverse societies. Laws, in complex societies, are designed around the concept of morality.

While this approach is dated, a single concept is central as an explanatory variable when discussing how laws change as societies change. This concept, morality, is essential to the cohesion of societies where the division of labour is developed. Canada is such a specialised society reflecting organic solidarity and a complicated division of labour. With respect to social cohesion, morality can act as social 'glue' between differentiated groups and their commitment to the broader social whole. Laws, defined through adherence to common and developing moralities, are constructed through social discourse and social action.

In complex societies, criminal law is designed to regulate and maintain public order, the division of labour in society and the social relations which sustain society (Durkheim 1984 p.173, Vago and Nelson 2008 p. 47). Criminal law is also designed to coerce and correct the behaviour of those individuals who do not consent to behave in 
socially approved manners (Boucock 2000, p.46). If law is constructed around varying forms of social and anti-social behaviour, how is it that society collectively determines what is good and what is bad behaviour? Further, how does this theory explain the possibility that many individuals can have differing perceptions of good and bad, yet the majority consent to behaving in socially approved ways?

The link between law and definitions of social and anti-social behaviour is morality. As such, laws are reinforced by collective moralities shared by social participants. Thus, behaviour constructed as anti-social is in violation of common perceptions of morality, and the unification of these perceived moralities is described by Durkheim as the collective consciousness:

Crime, as we have shown elsewhere, consists of an action which offends certain collective feelings which are especially strong and clear cut... (Durkheim 1982, p.99).

Moreover, Durkheim identifies how different moral perspectives can be co-existent:

But such universal and absolute uniformity is utterly impossible, for the immediate physical environment in which each one of us is placed, our hereditary antecedents, the social influences upon which we depend, vary from individual to another and consequently cause a diversity of consciences (Durkheim 1982, pp. 100).

The collective consciousness can be interpreted as a collection of moralities, bound by common social goals. Further, the importance of moral behaviour can be seen where "social cohesion depends on moral commitment to the collective welfare" (Cotterell 1992, p.76). In the theoretical approach adopted in this thesis, morality implies "relations between consciences" (Jones 2001, p.184), which help to produce a somewhat predictable mode of interaction among social actors (Durkheim 1982 p. 99, Boucouck 
2000 p.45, Ben-Yehuda 2006). Moralities are then best defined as communicated constructs of ethical and socially approved behaviour, which are transmitted and applied in social relations:

Morality is a universal set of criteria which is culture specific and tells people how to distinguish between right and wrong, beautiful and ugly, good and bad. The specific content/s of these universal sets of rules may have great variability among different cultures and consequently, what morality actually means may differ from one culture to another. However, morality tells members of specific cultures what appropriate behaviour is... (Ben-Yehuda 2006, p. 562).

In this sense, morality does not imply unchanging eternal rules of behaviour, though it does imply that the majority of social actors recognize the necessity of law and thus consent to the rule of law. Further, while social cohesion and its relationship to morality may imply a homogenous society, social cohesion in the approach taken in this thesis does not. Rather, social cohesion "is not based on uniformity of values...but on functional interdependence of differentiated groups in society" (Cotterell 1992, p.77). Organic solidarity, and its necessary interdependence of social actors, is made possible by the sharing of common goals and values amongst members of a particular society; this sharing occurs through collective consciousness and the pervasiveness of common moralities.

Morality, a commitment to other social actors and to the development of a safe and reproducible society, is the impetus for determining which forms of behaviour are approved. If a form of behaviour is defined as anti-social, we typically construct laws to protect against it. In Durkheim's words, "[c]rime therefore draws honest consciousnesses together, concentrating them" (Durkheim 1984, p.58) and from this commonality laws 
are designed to regulate behaviour to this extent. Those who contravene laws are punished since "once moral statements are made, legitimized, and accepted, they have to be enforced" (Ben-Yehuda 2006, p.563).

The theoretical approach outlined above also provides an understanding of social change since it suggests that as the values of social actors and social groups change, the possibility exists for laws to change as well. While not all social actors and social groups agree on which forms of behaviour should be accepted, social cohesion can be achieved when the majority of social actors and groups, regardless of differentiation, recognize mutual obligations in law which create a safe and relatively predictable daily life (Schmaus 2004, p.134). In Durkheim's words, "law and morality vary from one social type to another, but they even change within the same type if the conditions of collective existence are modified" (Durkheim 1982, p.101). This last point is further elaborated:

Where crime exists, collective sentiments are not only in the state of plasticity necessary to assume a new form, but sometimes it even contributes to determining beforehand the shape they will take. Indeed, how often is it only an anticipation of the morality to come, a progression towards what will be! (Durkheim 1982, p.102).

In other words, perceptions of morality are necessarily dynamic and fluid, providing the opportunity for transforming what is defined as approved behaviour or introducing new kinds of behaviour. This supposition is reinforced by Ben-Yehuda:

Like so many other social phenomena, the natures of deviance, its definition, and what are considered the proper responses to deviance change. Deviance is a relative phenomenon among cultures and over time within cultures. Researchers have known, discussed, and written about this issue for dozens of years (Ben-Yehuda 2006, p.561). 
This flexibility in defining acceptable behaviour is the basis for a theory of social change. While unapproved actions can be criminalized and moralized at one point in history, they can be perceived as revolutionary and transformative at another (Mills 1959 p.37, Jones 2001 p.184). Further, changes in the perception of social behaviour can necessitate changes to the laws associated with the behaviour in question (Durkheim 1984 p.331, Ben-Yehuda 2006), since we exist in a socio-legal system that recognizes the "importance of the reciprocality of relations to define power in a democracy" (Jones 2001, p.173). The theory employed in this thesis, while examining how laws are constructed around morality, is also a theory of how society changes through the functional development of morality and law.

Applying functionalist theory helps to explain how large heterogeneous societies mediate the lack of consensus over what is defined as acceptable behaviour and interpret how societies create law (Ben-Yehuda 2006, Vago and Nelson 2008). This is especially useful since the theory helps to explain how various individual actors are capable of developing dissent or agreement when discussing the legitimacy and role of law in society.

Judges, as individual actors, are part of this social construction of what is considered right and wrong behaviour. Moreover, judges are in a position of significant power since they are capable of ruling on law and at the highest levels, such as the Superior and Supreme Courts, and are able to diminish the perceived legality of specific laws. In short, adopting a functionalist perspective helps to define judges' sentencing acts as both institutional, in so far as they must play their part in regulating the behaviour of 
citizens, and as reflections of their individual beliefs and legal opinions. It is these opinions that this research seeks to examine.

The approach described above has been applied in studies similar in nature to this thesis. It has been used in research which examined the effects of morality on the construction of law and criminality; it has been used to guide the study of dramatic changes in criminal behaviour following economic and social collapse in the former Soviet Union (Pridemore and Kim 2007); it has also been used to investigate the increasing suicide rates of young African-Americans in a society that continuously devalues collectivism and diverse social networks (Willis and Coombs et al. 2002). More specifically, it has recently been updated by Nachman Ben-Yehuda in an analysis of how deviant behaviour is defined and redefined in a social and moral context (Ben-Yehuda 2006).

In summary, Durkheim's updated functionalism is adopted as a theoretical lens in this thesis since it conceives of law as a product of the moralities shared by social actors, social groups, and institutions. This is important since in this study we examine the behaviour of judges who are responsible for upholding a law about which they may have conflicting responses and opinions. Given the contested nature of cannabis laws in Canada, the position of the judiciary is important since it may have an impact on social and legal change with respect to cannabis. 


\section{CHAPTER 3: LAW, ENFORCEMENT, DISCRETION, AND THE JUDICIARY}

It is necessary to examine how and where our laws are enacted prior to discussing how the police and the judiciary can respond to various cannabis offences. Politicians are responsible for designing and redesigning laws in relation to current moral and social trends. In the cannabis debate, politicians are responsible for weighing arguments made in the public debate and making policy choices which they deem to be in the best interest of Canadian society. The debate surrounding cannabis and cannabis law has been going on for many decades. As the debate unfolds, there is significant disagreement as to what is considered moral and what is defined as legal since more and more citizens are taking sides in the cannabis debate. As the debate intensifies, the effect it has on our politicians and the bureaucracies involved in upholding and regulating cannabis laws grows stronger. Specifically, the influence grows stronger on the criminal justice institutions that monitor illegal behaviour, apprehend criminal offenders, and punish them for antisocial behaviour. Individuals in those institutions charged with upholding the law are influenced by the cannabis debate since they participate in the censure of acts deemed illegal. They are, in part, capable of transforming how anti-social behaviour is perceived by participating in the identification and processing of what constitutes anti-social behaviour. By applying the concept of discretion when choosing to enforce or apply laws, actors in the criminal justice system can change not only how they perceive criminal acts but how society in general perceives and defines what is criminal. The following chapter puts the Canadian cannabis debate in context by outlining the varying approaches to cannabis by police, Canadian law, and the criminal courts. 
The following discussion examines the concept of discretion and relates it to the application of the law by members of the criminal justice system. The discussion will examine evidence of discretionary acts by police officers enforcing cannabis laws as well as how judges can use discretion when adjudicating cannabis cases. It is through the utilization of discretion that members of the criminal justice system can, in a subtle way, respond to social and legal phenomena while respecting and testing the boundaries of laws (Macdonald et al. 1999, Macdonald and Erickson 1999). First, the discretionary practices of law enforcement officers in relation to cannabis are discussed. This is followed by a discussion regarding the nature of judicial discretion. Next, an outline of Canada's drug laws is provided. This is followed by a discussion of sentencing maximums and what sentences are available for Canadian cannabis offenders. Finally, an examination of the actual limits to judicial discretion is presented, describing sentencing as a dynamic and complex process.

Police discretion is visible and well researched in the sociology of law and criminology (Davis 1975, Lundman 1980, CCJS 1999, Schulenberger 2003, Warburton et al. 2005). Discretion by enforcement institutions is necessary, yet the use of discretion shows how the focus of law enforcement shifts as criminal behaviour patterns or policy concerns change (Hall 1978). Time, money and resource constraints do not allow enforcement agencies to deal with all cannabis offences since too many citizens consume cannabis for total enforcement of all crimes. While discretion can be used to mediate uncertainty and ambiguity, discretionary practices can also suggest that there is a lack of consensus pertaining to specific laws. 
There is specific evidence to show that police practice discretion when confronting minor cannabis infractions such as the possession of small amounts (Atherton, Davis 1975, CCJS 1999, Miller 2000, Warburton et al. 2005). There are guidelines to discretion, and it is recommended that officers enforce cannabis laws when they witness the following: someone who publicly smokes cannabis; someone known to be a dealer; someone who has been identified as a public nuisance; or someone with cannabis who is discovered in close proximity to youth (Warburton et al. 2005, p.117). These guidelines have been developed by lawmakers, law enforcement officers, and policy analysts. Another guide for when discretion should be applied is when "the social and economic costs of enforcement [and prosecution] outweigh the benefits of regulation" (Shiner 2003, p.777). This is a measure by which police officers themselves often gauge when to use their discretion in arresting and charging cannabis offenders. British researchers have shown how these guidelines are developed in reference to political, legislative and social discourses:

There was a sense in the media that the political mood on cannabis was changing. In 2001, the parliamentary Home Affairs Committee announced that it would mount its own inquiry into the drugs legislation. At the same time, various senior police officers were advocating the legislative reform, some actually calling for the [discretion] legislation. In June 2001, the Metropolitan Police Service introduced a pilot project... in which officers delivered formal on the spot warnings to those found in possession of small amounts of cannabis (Warburton et al. 2005, p.115).

A similar program was introduced in Canada during the late nineteen-nineties (CCJS 1999, p.5), though the degree to which formal discretion policies are adhered to over informal policies is unknown. Nevertheless, documentation supports the position that the police use discretion in cannabis cases. 
Police discretion can be applied in circumstances involving cannabis since narcotics investigations are costly, time consuming and require court time on the part of the arresting officers. In general, narcotics enforcement takes up almost half the budget of some Canadian police forces for 'effective' regulation (CID 2005, p.9) and recent studies have shown that "in Canada, $90 \%$ of federal expenditure [pertaining to illicit narcotics] is spent on supply reduction" (Kisely 2005, p.156). Regardless of how large budgets get for narcotics enforcement, it is reiterated by Canadian police sources that more cannabis regulation is necessary (OACP 2002, CID 2005).

There are contrasting opinions regarding cannabis among the police themselves and the civilian oversight groups that monitor police activity; some support change while others do not. However, the opinions of senior officers carry more weight and they directly influence the enforcement actions of individual officers in their organizations. The existence of police discretion in responding to cannabis offences reveals how the cannabis debate moves from a public debate to a debate in administration of law enforcement, to a transformation in real enforcement practices (Atherton, Davis 1975, CCJS 1999, Miller 2000, Warburton et al. 2005). The practice of discretion by individual police officers can reflect the informal policies found in various police departments.

Further, while police officers practice discretion in apprehending and detaining cannabis offenders, prosecutors can decide whether to pursue or to drop charges laid on offenders. This discretion is important since it shows that at all levels of criminal justice, discretionary acts are taking place. Finally, while there is not a great deal of room to discuss prosecutorial discretion, Crown prosecutors have policy supporting the exercise of discretion for various types of criminal offence cases: 
Crown counsel have a broad discretion to conduct cases to ensure that justice is done in individual circumstances. This prosecutorial discretion is necessary to allow Crown counsel to respond to unique circumstances in cases including victims, offenders, and local conditions. Prosecutorial discretion, when exercised fairly and impartially, is an essential component of the criminal justice system (Role of the Crown, p. 4).

Since the police represent the 'beginning' of an offender's entrance into the criminal justice system, it is fitting to move from policing to the sphere of the judiciary, since it is in the courts, under the authority of a judge, that the determination of guilt for violating moral and legal boundaries is rendered. However, evidence of possible responses to cannabis from the judiciary are not as public or visible as the actions of politicians, activists or even police officers (SAFER 2007, CAPB 2005, Health Canada 2005, Benoit 2003, Kenny and Nolin 2003, OACP 2002, Lundman 1980). There is little published research on the responses of the Canadian judiciary to cannabis, though the existing research shows that they differ in their responses (Macdonald et al. 1999, Macdonald and Erickson 1999).

As noted above, it is clear that individual judges can apply discretion when determining innocence or guilt as well as when deciding on an appropriate sentence. This discretion has been documented in sociological, criminological, and various legal studies (Alpert 1982 p. 93, Lacey 1992, Himma 1999, Macdonald et al 1999, De Gaay Fortman 2006). According to MacDonald et al., "Canadian judges have more discretion in passing sentences than judges in all other Anglo-American jurisdictions" (1999, p. 278). Importantly, research has shown that "discretion... is influenced by several case, offender, social, and criminal justice process characteristics" (Miller and Sloan 1994, p.110). Individual judges apply discretion when adjudicating and sentencing those offenders who 
have violated the rule of law (Alpert 1982, Miceli and Cosgel 1994, Himma 1999, De Gaay Fortman 2006). Judges in Canada are likely to reflect a broad range of opinion on cannabis laws. This is well documented by Scott MacDonald and Patricia Erickson, who note that indeed, a difference of opinion may exist among judges:

Since all judges have high formal educational requirements, they might be expected to be predisposed to consider evidence that favours new directions in sentencing. On the other hand they may also have a vested interest in the status quo, as reflected in current criminal law and practices (Macdonald and Erickson 1999, p. 18).

This theme of discretion is further developed by other researchers who note the personal nature of discretionary practices from the bench:

Combined with the doctrine of individualization (punishment/treatment to fit the offender rather than merely the offence), the effective result has been that a sentencing judge is free to do whatever he thinks appropriate in any given case with no standards to guide or limit his discretion other than his own conscience and the attitudes he brings with him to the bench (Hoffman and DeGostin 1975, p.196).

Researchers have also suggested that "what might be seen as an aggravating factor by one judge was viewed as a mitigating or neutral factor by another [judge]" (Macdonald et al. 1999, p.276). Given this situation, both dissent and agreement with cannabis laws may be possible responses from judges.

The use discretion by judges and their interpretation of existing morality has been examined by Ronald Dworkin. He states:

My claim, to repeat, is that legal reasoning presupposes a vast domain of justification, including very abstract principles of political morality, that we tend to take that structure as much for granted as the engineer takes most of what she knows for granted, but that we might be forced to re-examine some part of the structure from time to time, though we can never be sure, in advance, when and how (Dworkin 2006, p.56). 
Put simply, Dworkin suggests that judges can, and do, listen and respond to political, social, and legal debates. While judges can exercise their discretion in court, they can also be vocal outside of the courtroom; for instance, an Ontario Court Justice recently agreed with a barrister that Canada's current cannabis possession laws were unconstitutional (Javed 2007). Further, judicial discretion serves to make our criminal court system less of a 'machine' which awards sentences for like offences in a cookiecutter fashion. Eliminating discretion would not serve the purposes of justice nor rehabilitation, two integral goals when sentencing criminal offenders:

It is monumentally important that the sentence passed fits the offender... The sentence must also fit the offence. Passing a sentence that is disproportionately harsh or woefully lenient as compared to the offence in question or the circumstances in which it was committed may result in the erosion of public confidence in the justice system. Without that confidence, the system cannot endure for long (Nsereko 1999, p.364).

In other words, discretion is a necessary component of the justice system. When confronted with offenders, judges must weigh facts, determine guilt and decide to what extent an offender should be punished. However, legislation affects how judges can practice sentencing. Prior to discussing the limitations to judicial discretion, it is important to examine Canadian narcotics laws as well as how cannabis and other narcotics are classified and referenced by Parliament and the Courts.

\section{The Controlled Drugs and Substances Act and the Schedule of Narcotics}

Canadian narcotics legislation can be found in the Controlled Drugs and Substances Act. ${ }^{1}$ Passed by Parliament in 1997, the Act repealed the Narcotics Control

\footnotetext{
${ }^{1}$ A hyper-link to CanLii, an electronic database of Canadian legislation is provided: http://www.canlii.org/ca/sta/c-38.8/
} 
Act as Canada's illicit substances legislation. The Controlled Drugs and Substances Act outlines all narcotics offences available for prosecution in Canada as well as sentencing maximums recommended for those found guilty of violating the statute. The following discussion outlines the sections of offences found within the Act. Next, a discussion is presented of how the criminal justice system distinguishes between various illicit substances. Note that these offences are listed as they are found in the Controlled Drugs and Substances Act; the degree of their seriousness is provided by justice and law enforcement institutions (CCJS 2006). It is also necessary to discuss narcotics legislation and the rationales for punishing offenders since it is around the legislation that a lack of consensus emanates. This is followed by an outline of the key limitations to judicial discretion. Note that the sections of the Controlled Drugs and Substances Act described below refer to the offences studied by this thesis.

Note that there are limits to the offences studied in this thesis. First, there is no inclusion of summary offences or hybrid offences. All charges in the data to be analyzed are indicted offences which were brought to court. This limitation is a limitation of the data used in this project. However, while there is no distinction of the other types of charges, the sentence maximums listed below are relational to the data set's indicted offences. Though the inclusion of summary offences, those which are dealt with expediently and with lesser punishment by the criminal justice system, and hybrid offence, those offences where the Crown decides whether to indict or to treat the offence as a summary, would add detail and nuance, this limitation is a reality to the data produced by the government and used in this study. 
"Possession of Substance", found in section 4 , is the first offence in the Controlled Drugs and Substances Act. Section 4 defines possession as having small amounts of a controlled substance on the body and/or the property of an individual. Amounts of substance are differentiated with respect to section 4 in the Controlled Drugs and Substances Act. This differentiation exists to prevent narcotics producers and traffickers from being prosecuted for simple possession. On a scale of harm, possession is considered the least harmful of offences in the Act (CCJS 2006). Possession is the largest source of controversy regarding cannabis in Canadian justice. Cases such as R. v. MalmoLevine (2003) and R. v. Krieger (1998), as well as some recent judicial remarks made in Ontario, have raised questions regarding the unconstitutional nature of cannabis possession laws (Javed 2007).

Section 5 deals with offenders who traffic in narcotics. "Trafficking in substance" represents the unique offence of trading narcotics for monies, goods, or other illicit substances. Trafficking is considered to be one of the most harmful offences listed in the Controlled Drugs and Substances Act since 'dealers' are seen as the direct profiteers in the narcotics black market.

Section 6 deals with the importation and/or exportation of controlled substances into as well as out of Canada. "Importing and Exporting" is a serious offence due to its international nature: it requires the crossing of borders and the violation of international substance control legislation. Importation/exportation is important to the cannabis debate since much Canadian cannabis is exported to the United States. As a result there is a great deal of pressure from the United States regarding Canadian cannabis laws (Benoit 2003 p.280, The White House 2007). 
Production of narcotics is a key part of the Canadian narcotics discourse. Section 7 deals with those offenders who have constructed illicit production sites to create controlled substances for sale. "Production of substance" defines the illegal behaviour of individuals and organizations that grow cannabis, cook methamphetamines, and mix crack, among others. Section 7 offences are considered very serious since the offences themselves represent the source for many of Canada's illicit narcotics.

To summarize, the sections of the Controlled Drugs and Substances Act describe the offences that were examined in this study. Before developing a discussion of how judges can and cannot respond to cannabis in their courts, it should be outlined how cannabis offences are classified and described when they are brought before a criminal court. Understanding how narcotics are classified will provide the reader with a nuanced look at how drugs are defined by our government and portrayed in our courts.

All narcotics in Canada are listed in the Schedule of controlled substances; Tylenol, Nyquil and other commercially available narcotics are found in the same tables as cannabis, heroin, and methamphetamine. The Schedule is not a hierarchy of aggravating drugs, but rather several groups of substances categorized according to chemical family and derivation. Most popular illicit substances belong to a single section of the Schedule. Cannabis is unique. Cannabis falls under three Schedules: Schedule II, Schedule VII and Schedule VIII. Schedule II regulates cannabis as a species. First, Schedule II states that any part of a cannabis plant is illegal. This includes fibrous materials and leaf products as well as the 'bud' used for narcotic effects. The Schedule VII classification outlines large amounts of cannabis bud, focusing on weights of equal to or over 3 kilograms. Schedule VIII refers to amounts of less than 30 grams (1 ounce). 
The Schedule helps prosecutors determine which offences are more harmful due to the weight and nature of the substance involved. It is noteworthy that charges and sentencing often depend on the weights of cannabis involved as well as the type of crime committed.

\section{Sentencing Principles and Cannabis Sentencing Maximums}

The Controlled Drugs and Substances Act uses sentencing to create respect for the law, encourage a safe society, develop the rehabilitation of offenders, and make the offender aware of the harm they have caused others (CDSA, section 10, Subsection (1)). In the Canadian Criminal Code, section 718 outlines the general principles involved when sentencing offenders. While the Controlled Drugs and Substances Act has its own sentencing principles, judges are reminded to keep criminal code sentencing principles in mind when determining appropriate sentences for cannabis offenders. A major consideration when sentencing narcotics offenders, however, lies in section 10 of the Controlled Drugs and Substances Act, where the principles of rehabilitation and treatment are considered crucial (Brauti and Puddington 2003, p. 326). Thus, while section 718 of the criminal code outlines deterrence, denunciation, among other principles, it is within the Controlled Drugs and Substances Act that the principles of rehabilitation and treatment are added. These added principles may transform the responses of judges as they apply sentences to offenders since it is clear from the legislation that their crimes are different from crimes where only section 718 principles apply.

From a sociological perspective, sentencing can be seen to promote social control and the regulation of anti-social behaviour, as outlined in the functional theory discussed 
earlier (Durkheim 1984, Schmaus 2004, Ben-Yehuda 2006). Deterrence is a cornerstone of how the law manages public and private behaviour:

The principal justifications fall into one of two categories. One purpose is the attempt to reduce the level of crime in society by deterring others from committing offences... Sentencing purposes of this kind are called reductivist, because they aim to reduce crime rates by preventing crimes that might otherwise have been committed (Roberts and Cole 1999, p.5).

The concept of deterrence is an important one when discussing the punishment of offenders since it ties retribution, incapacitation, and rehabilitation or treatment to what is otherwise interpreted as simply a punitive act (Macdonald et al. 1999, p.275).

Deterrence is used for two reasons: specific and general deterrent effects. The differences between the two lie between the focus on broader society (general) and the individual offender (specific).

General deterrence looks to "discourage other potential offenders from offending" (Roberts and Cole 1999, p.6) while specific deterrence seeks to "make the individual refrain from further offending through fear of the consequences of reconviction" (Roberts and Cole 1999, p.7). General deterrence fails since the "general public, including potential offenders, seldom hear about sentences imposed for deterrent purposes... potential offenders cannot be deterred if they are unaware of the penalties for particular crimes" (Roberts and Cole 1999, p.6). Research on specific deterrence is less certain: some agree that it fails alongside general deterrence while others see it working in preventing offenders from recidivating. Some argue that specific deterrence works since it leaves offenders with a bad 'taste' for punishment (Homel 1988). Others report that recidivism rates are influenced by factors other than punitive measures, such as the poverty and life circumstances of criminal offenders (CCJA 2006). 
With reference to cannabis, the principles of deterrence may be less effective since the definitions of legality are questioned by many:

If prohibition does not deter some from trying illicit drugs, many are not deterred and, for some, the forbidden status of the drug is actually attractive. Informal social controls and socio-cultural norms may be more important than formal controls in influencing drugs use (Kisely 2005, p.157).

This is a strong, critical appraisal of narcotics laws and their deterrent effect, suggesting that since deterrence in sentencing is not guaranteed, its failure may propagate and perpetuate illicit narcotics use as long as social definitions of drug use differ from what is prohibited in existing drug laws. However, regardless of whether deterrence works, it is used as a justification for the punishment of criminal behaviour. Judges are responsible for applying deterrence as a rationale for punishment when awarding sentences. In the analysis that follows, deterrence is a key concept that is examined in relation to the rationales provided by judges for the sentences they give to cannabis offenders.

After a disposition of guilt has been rendered by the court, offenders are sentenced for specific violations of the Controlled Drugs and Substances Act. Individuals found guilty are brought before judges who award what they feel are appropriate sentences, often taking into consideration the recommendations of Crown prosecutors and defence counsel. This is especially important since it shows that sentencing is ultimately the responsibility of the judiciary. However, the Controlled Drugs and Substances Act does provide maximums with respect to the types of sentences and maximum sentence length that can be imposed for specific offences. These maximums are decided by the legislature with respect to the crimes committed and the substances involved. 
Each section of the Controlled Drugs and Substances Act has its own sentencing maximums related to particular categories of substances. Sentencing of cannabis offenders, like other narcotics or criminal offenders, is based on case law, the maximums provided, and the discretionary power of the judiciary. Case law represents current trends in sentencing: it reflects the 'average' sentences that other judges have applied in sentencing cannabis offenders. The only absolute restriction the judiciary currently faces when sentencing is when applying maximum sentences. These are outlined by Schedule in the Controlled Drugs and Substances Act. Note that "the maximum penalties for cannabis offences, if lesser quantities are involved are significantly lower than for cocaine or heroin...however, importation and exportation of cannabis remains a serious offence and the maximum penalty remains life imprisonment" (Quann 2003, p.2).

Cannabis importation has been omitted from the following discussion as well as the data to be analysed. This was done for two reasons. First, cannabis importation is not a common offence. Secondly, the data used in this study does not define cannabis importation individually, due to the low frequency of importers who are smuggling cannabis into Canada, as opposed to the more common practice of smuggling cannabis out of the country (The White House 2007). Those who smuggle out of Canada are typically prosecuted by the country of import.

Section 4(5) of the CDSA defines offences pertaining to the possession of illicit narcotics. Possession of cannabis in amounts less than Schedule VIII (30 grams or less) can result in incarceration for no more than 6 months, a fine of up to $\$ 1000$, or a combination of the two. In section 4(4), possession of a Schedule II substance in nonSchedule VIII amounts, carries a maximum sentence of five years imprisonment. Note 
that these sentences are maximums and do not outline the full range of sentence types available to a judge.

Section 5 discusses illegal trafficking of narcotics. Trafficking Schedule VIII amounts of cannabis, fewer than thirty grams of cannabis, carries a maximum sentence of 5 years incarceration. Those charged and convicted of trafficking cannabis in Schedule VII amounts, that is amounts equal to or more than three kilograms, face the possibility of being sentenced to incarceration for life.

Section 7 of the Controlled Drugs and Substances Act describes the illegal production of narcotics. For those found guilty of cannabis production, the maximum sentence is seven years incarceration. Note that in the production of harder drugs, such as methamphetamine or crack, the imprisonment maximum includes the possibility of a life sentence.

The type and length of sentences given by a judge can be an important indicator of the judge's assessment of the crime committed. Describing the practices of the judiciary requires looking at the limitations, beyond sentencing principles and maximums, faced by judges when they sentence cannabis offenders. These limits are the focus of the next section.

\section{Limits to Judicial Discretion: Appeal, Case Law, Sentencing Maximums and Perceived}

\section{Harm}

While drugs laws and sentencing maximums have been discussed, it is important to note that there are several constraints to judicial discretion when judges determine sentences for offenders. In some instances, the discretion of judges is checked, altered, or 
revoked. Even though a judge's use of discretion is an essential component of the justice system (Nsereko 1999), judges still face several constraints when practicing sentencing.

Reviewing the decisions and practices of judges is a necessary procedure to maintain a consistent application of the law (Miceli and Cosgel 1994, Trotter 1999). These reviews can take place in several judicial and professional venues including "sentencing institutes, sentencing councils, appellate review of sentencing, providing written reasons for sentences, and the formulation of explicit sentencing policy," (Hoffman and DeGostin 1975, p.197) the last of which has already been outlined in the above discussion regarding sentencing maximums. While judges have the power to sentence, their sentences are not absolute: they can be challenged on matters of law in the context of common law practice. The most common constraint to a judge's sentencing practice is the process of appeal (Lacey 1992). If a sentence is considered unfit in light of the common practice of law or if a minimally harmful offence is punished with an excessive sentence, an appeal can be filed:

Appellate review is a.... technique proposed for controlling sentencing discretion. Proponents argue that even the possibility of appellate review would tend to make judges reflect more carefully on their sentences... [However] experience in several jurisdictions in which appellate review has been available seems to indicate that it has achieved, at best, only a small reduction in the most excessive sentences (Hoffman and DeGostin 1975, p.197).

The appeal court will re-evaluate the punishment awarded and determine whether the sentencing judge was in error when determining the appropriate punishment for a particular offence. Furthermore, looking towards case law and the practices of other judges has a strong influence on judicial discretion:

Judges frequently turn to the cumulative and evolved wisdom of judicial experience represented by precedent for their decisions and also place 
particular emphasis on their personal experience. This 'experience' helps judges to interpret and schematise the mass of information with which they are presented (Tata 1998, p.215).

Constraints from the appeal process can affect the way judges behave. However, appeal courts are very reluctant to alter the decisions of the trial judge; nevertheless appeals are still a possible limitation to a judge's sentencing practice. The importance of one's reputation within the judiciary may influence a judge's response:

If the opinion presented by a judge appeals to others, the precedent set by him may be followed. The citations (explicit or implicit) received by the judge will in turn enhance his reputation and increase prestige within the legal community. Conversely, a failed attempt at setting a precedent is likely to take away from the reputation of a judge. A reasonable objective of a judge therefore might be to choose actions that will increase his reputation positively (Miceli and Cosgel 1994, p.35).

Conscious of their own appearance to the judicial bureaucracy and their peers, judges may be reluctant to make a marked departure from existing sentencing practices in cannabis cases. While this refers to both formal and informal restraints to judicial discretion, further constraint to on their actions lies in the Controlled Drugs and Substances Act itself.

The sentencing maximums drafted by the legislature, discussed earlier with reference to cannabis offences, are strong limitations to judicial discretion (Tata 1998, p.205). Furthermore, sentencing maximums limit the maximum awardable sentences. In an interesting turn, it may be that these maximum sentences are restricting the discretion of those judges who feel sentences are too lenient for Canada's narcotics offenders. For example, if a maximum sentence for a particular crime is a fine of $\$ 2000$, a judge will be in error if a custodial sentence of any length is given. Errors such as these translate to performance reviews discussed above and appeals being found in favour of the offender; 
these reflect poorly on a judge's tenure. However, limiting maximum sentences rarely denies judges their right to exercise discretion, though any act which restricts their behaviour technically alters their ability to employ discretion. For example, instead of maximum sentences, some offences have mandatory minimum sentences which judges must apply. It is the implementation of these mandatory minimum sentences that some legal scholars argue will "remedy... the problem of unwarranted sentencing variation" (Hoffman and DeGostin 1975, p.197) while leaving judicial discretion largely unaffected. Other scholars argue that by removing discretion through the implementation of mandatory minimum sentences, the legislative assembly effectively reduces the discretionary power of a sentencing judge and replaces it with a functionary role:

Where Parliament withholds or restricts the discretion of the courts to adjust the sentence according to the circumstances of each case injustice invariably ensues. The sentence meted out may not fit the offender. The sentence may create other deleterious social problems either for the offender or for his family (Nsereko 1999, p. 365).

It is noted that discretion is an essential component to fitting the goals of sentencing to punishment.

An important factor when determining an appropriate sentence is the type of crime committed and the harm involved. It is understood that if the perceived harm of a crime is high, the type of sentence should be commensurate with the offence (Roberts and Cole 1999, p.10). Since the criminal justice system is designed to regulate and punish anti-social behaviour, the type and length of sentence must depend on the crime committed (Nsereko 1999, Roberts and Cole 1999). This suggests that if a crime is morally and socially shunned, such as aggravated sexual assault, it should receive a severe sentence such as a long period of incarceration. It is possible, through the 
application of discretion, that shunned acts can be punished too leniently. This violates the principle "that [the] sentence should be proportionate to the seriousness of the offence and not based on the character or past conduct of the offender" (Tata 1998, p.204). Curtailing discretion, some argue, is the solution to the possible existence of lenient sentencing practices. While incarceration is a simple response to aggravated offences, acts perceived as less harmful crowd the justice system and have no easy sentencing 'answer'.

Criminal justice institutions produce seriousness rankings to determine how harmful specific crimes are (CCJS 2006, p.239). These rankings are produced by Statistics Canada in consultation with legal scholars, prosecutors, and, of course, criminal justice statisticians. The rankings are, in part, based on reported crime rates, court survey data, and current 'moral political' trends, as mentioned by Ronald Dworkin earlier. The rankings are constructed through analysis of the Adult Criminal Court Survey ${ }^{2}$ in which a rank is given to an offence based on the offence's likeliness of receiving an aggravated sentence. As such, one could argue that the seriousness rankings themselves are socially developed; a crime considered heinous and worthy of incarceration, as sodomy was considered in the past, would rank as serious until social and political pressures transformed the law, and the likelihood of receiving a penal sentence was eliminated.

Cannabis offences are ranked low in seriousness statistics, ${ }^{3}$ and it is interesting to question whether this ranking for cannabis will disappear as more Canadians question the legality of cannabis laws. Perhaps the decline will accelerate as judges play a more

\footnotetext{
${ }^{2}$ A survey of all court cases, the number of defendants, victims, type of crime committed, the cost of the crime committed, and the various nuances found in criminal court cases.

${ }^{3}$ See Appendix III for these rankings
} 
visible role in the social debate surrounding cannabis and cannabis laws. However, the rankings have little effect on judicial practice since "the relative inflexibility of numerical guidelines considerably reduces the element of judicial discretion in sentencing and they have thus not been popular with judges" (Tata 1998, p.205). What little effect these rankings may have on judicial discretion also vary as times change since the criteria for 'serious' offences change with varying social, moral and political concerns. This dynamic is outlined in the theory chapter as well as by the very processes, discussed above, by which seriousness rankings are constructed.

This thesis suggests that the judiciary's responses are visible even though the law, sentencing maximums, principles of sentencing and the limitations to judicial discretion might serve to mask them. In the next chapter, the discussion focuses on the cannabis debate, the participants and organizations involved, and the arguments put forward by various sides. It is necessary that we touch on the cannabis debate after discussing the judiciary's role since it is this debate that may alter the practices and opinions of individuals in the criminal justice system, including the judiciary. 


\section{CHAPTER 4: THE CANNABIS DEBATE}

Disagreements over what kinds of behaviour are moral and what practices are legal are an integral part of the ongoing development of law in society. In this thesis, the literature review shows that cannabis is the subject of a socio-legal debate. This debate involves politicians, doctors and the chronically ill, as well as various decriminalization and regulation advocacy groups. The cannabis debate has a developed history in Canadian society. When Canada criminalized cannabis in 1923 , it was among the first nations to do so, occurring even before the prohibition of the plant in the United States (Erickson and Oscapella 1999, p.313). It is therefore particularly noteworthy that in the past 10 years, there has been a shift in attitude in politics, medicine, and society with respect to this contested substance.

Unlike other illegal narcotics such as crack cocaine or methamphetamine, cannabis has long been perceived by many Canadians as a recreational and social narcotic. It is clear that cannabis is differentiated from other illicit substances in Canada since the debate over it is well publicized and the participants are vocal; crack and methamphetamine, by contrast, do not have legalization lobbyists and popular social movements supporting their liberalization. Furthermore, academic and journalistic research suggests that almost one in two Canadians is in favour of decriminalizing cannabis (Khoo 2001). Public interest in the debate has an effect on Parliament. It is expected that Parliament will respond via legislative change, much like the previous Liberal government had attempted with its proposed decriminalization legislation. The Government of Canada's past responses to cannabis use include two major reports focusing on cannabis and the Canadian social, political, and legal perspectives on it. 
Cannabis has been debated thoroughly in Parliament over the past 10 years. Though it might periodically fade out of the headlines, cannabis re-appears for each consecutive sitting of the House of Commons. The most drastic action regarding the redrafting of cannabis law in response to growing social activism and debate occurred early in the twenty first century. The Government of Canada began in 2002, under Liberal leadership, a concentrated legal effort to decriminalize the possession of small amounts of cannabis, tabling Bill C-38: An Act to amend the Contraventions Act and the Controlled Drugs and Substances Act. This amendment would have redefined how cannabis laws were to be enforced and provided clearly defined punishment, something that does not currently exist in the dynamic case-based narcotics sentencing maximums. Instead of facing the possibility of a criminal record, offenders would have paid a fine similar to a parking ticket. In short, the repeal of cannabis specific legislation would have seen the general decriminalization of possession of small amounts of cannabis (Bill C38).

While the Bill appeared to focus on liberalizing cannabis use, it took a stronger stance than current legislation regarding other offences in the Controlled Drugs and Substances Act. The proposed amendments would have provided stronger sentencing guidelines for those who traffic and produce cannabis as well as a five year multi-million dollar National Drug Strategy to educate the youth and public about cannabis and other illicit substances (Bill C-38, Canada 2003). The Liberal government included these caveats to decriminalization to appease those who felt Canada was not ready for decriminalized cannabis, as well as to reassure their American drug policy counterparts that Canada was not placing cannabis related offences outside the regulation of law. The 
introduction of the Bill also echoed socio-legal movements in Britain, where liberalization was supported by police and the Parliament (Shiner 2003, p.775), showing that criminal deregulation of cannabis was not a uniquely Canadian idea. However, political influence from conservative opposition in Parliament and the looming federal election helped prevent the Bill from passing to the Senate. Bill C-38 was dropped in 2003 (StopTheDrugWar 2003). Little reform has occurred since then.

Though a change in government has shifted priorities away from the cannabis debate, there is still pressure from legal advocates and social groups to reform Canada's cannabis laws. Furthermore, cannabis has once again become a popular topic of discussion in news media, as is evident from the extensive coverage given to the grow operation scare of recent years (CTV 2007) and statements regarding the legality of certain Canadian narcotics laws (Javed 2007).

A discussion of the cannabis debate should start with an overview of the government's own research into cannabis since it is this research which is cited in almost all Canadian cannabis-related literature, as well as in many judgements handed down by Supreme Court, Provincial and Superior Court judges. Responding to the growing legal, moral and social debate, Canadian legislators have initiated two noteworthy investigations into cannabis. Each government investigation describes the social rituals involved with cannabis, the harms attributed, and the socio-economic and legal costs of prosecuting cannabis offences. The LeDain Commission's 1972 report provides a social and legal history of cannabis in Canada. Its investigation into the psychological and physiological effects of cannabis was without precedent in Canadian governmental drug 
research. It also investigated social issues such as unemployment, criminality and deviancy in relation to cannabis consumption and cannabis culture.

The LeDain Commission looked closely at the relationship between cannabis and anti-social behaviour and it reported that cannabis was not a significant cause of serious crime or violence (Canada 1972, p.110). This is probably its most important finding since it countered the common belief that drugs are inherently linked to criminal behaviour and criminal recidivism. By challenging the link between criminal behaviour and cannabis use, the LeDain Commission altered the way soft drugs were perceived. In a broader context, the LeDain Commission's findings reinforced the findings of President Nixon's Shafer Report on marijuana; a report that was widely criticized by the administration that initiated the study (Shafer 1972). The LeDain Commission's report remained the only major Canadian government sponsored work with a focus on cannabis for nearly 30 years.

Over a quarter century after the LeDain Commission, the Special Senate Committee on Illegal Drugs produced a report in 2002 outlining key elements of the Canadian cannabis debate for the twenty-first century. This report echoed the criminological findings of the LeDain Commission, yet went further into an economic analysis of how much Canadian tax money is spent every year in enforcing and prosecuting cannabis offences. At a glance, drug offences cost Canadian courts nearly $\$ 860$ million in 1996/1997 (Kenny and Nolin 2003, p.134); if cannabis represents one in every four drug offences, cannabis court cases cost Canadians nearly $\$ 216$ million in 1996/1997. These estimates were reinforced by outside research following the Senate Committee's investigation (Kisely 2005, p.157). Further, the Senate report reinforced the 
LeDain Commission finding that cannabis use itself is not related to rising crime rates or anti-social behaviour. The committee also found that many more Canadians are reporting being in favour of redefining the law surrounding cannabis. This provides evidence of shifting perceptions of morality and legality. Further, the committee produced statistics showing that over 500,000 ( $1.5 \%$ of 2007 population) Canadians currently have criminal records for cannabis offences (Kenny and Nolin 2003, p.138). Finally, the Senate Committee suggested the decriminalization of cannabis for possession related offences. This last recommendation was greeted with criticism by the Canadian Police Association (CBC 2002) and the federal opposition. However, the recommendation supported the implementation of Bill-C38 as discussed above. Ultimately, the Senate report updated and reaffirmed the findings of its predecessor.

These studies on cannabis have helped legislators make the decisions to regulate the medicinal use of cannabis through the Marihuana Medical Access Regulations (Health Canada 2005). Medicinal cannabis is a key topic in the controversial debate over cannabis in Canada. An important step in developing liberal social and legal perspectives on cannabis is embedded in the medicinal cannabis campaign. When viewed from the perspective of medicine, the opposing sides in the cannabis debate are less antagonistic. Even opponents of cannabis decriminalization in Canada recognize that the substance can alleviate suffering, much like other legally prescribed narcotics containing cocaine, opium, and methamphetamine. This opinion is reinforced by much Canadian medical research as is evident in the following example:

[T]his study finds that cannabis use is prevalent among this sample of chronic non-cancer pain patients, and effects are reported for a wide range of subjective symptoms. Health care workers need to be able to discuss 
cannabis use with patients and to be able to accurately describe possible risks and benefits of cannabis use (Ware et al. 2003, p. 215).

Further, medicinal cannabis activists and practitioners do not advocate the outright legalization of cannabis. Rather, they seek to make cannabis available for individuals suffering pain and chronic syndromes (MedicalMarijuana 2001) as well as to find new medicinal applications for the substance, such as for victims of multiple sclerosis (Pryce and Baker 2005). After nearly two centuries, following cannabis' introduction to Western medicine as a possible alternative analgesic to other more addictive substances (Mikuriya 2004), cannabis has a legislated and secure place as a medicine in Canada.

Legislation surrounding the use of cannabis for medicinal purposes makes clear that cannabis is a controlled substance, to be consumed under prescription like other narcotics issued to the ill. The legislation itself addresses medical uses of cannabis and does not address the issue of legalizing cannabis for personal use (MedicalMarijuana 2001, Health Canada 2005). The Government, by endorsing the medicinal cannabis program and supplying from its crop in Manitoba, explicitly acknowledges that cannabis holds the potential to relieve many chronic effects of illness, and must take this into account when gauging cannabis' place as a medication (Kenny and Nolin 2003, p. 124). Nevertheless the debate surrounding cannabis law is aggravated when cannabis is legal for some and not for others, regardless of the medicinal properties of the substance. Moreover, cannabis sees heightened levels of social, political, and legal activism. This is not a common phenomenon for other prescribed narcotics such as codeine, oxycodone, or ketamine. This suggests that many cannabis liberalization activists see more than medicinal uses for the plant product. Constitutional protection of medical cannabis use is a milestone for medicinal cannabis proponents. Medicinal cannabis is 
considered a major victory for cannabis liberalization since it is often viewed by legalization advocates as a stepping stone to decriminalization, helping to silence opposition by associating cannabis with medicine rather than crime.

There is a large political and social movement devoted to decriminalizing cannabis. This movement seeks to adopt and/or modify the Dutch model where cannabis is regulated yet legitimately available, and where the cannabis issue is not aggravated by making its use "taboo and pushing it underground" (Iversen 2004, p. 521). Those advocating decriminalization of cannabis seek to build upon the findings of the LeDain and Senate reports as well as the legislative changes made for medicinal cannabis use. They argue that cannabis use is not dangerous and that it should not be defined as criminal. Cannabis activists put forward two convincing arguments: 1) arguments for cannabis as an alternative to popular legal narcotics, and 2) arguments against institutional and bureaucratic redundancy in the federal governments' of Canada and the United States of America. Both arguments are dealt with separately.

Many activists make comparisons between cannabis and legal narcotics such as alcohol and tobacco (SAFER 2007). These comparisons are designed to suggest that cannabis is not as socially harmful as other narcotics. Reformers provide evidence supporting this position: there are no recorded overdoses with cannabis; violence is not significantly related to the substance; and the long term detrimental health effects are similar if not weaker than those of lifelong alcohol abuse and tobacco addiction (SAFER 2007). Responding to those who seek to keep cannabis regulated and criminal, cannabis activists assess the risk of using cannabis and re-evaluate prior scientific and political evidence regarding what cannabis can and cannot do: 
Thirty years later we are surely better placed to assess the real or imagined hazards of cannabis use. We know that millions of young people have taken the drug without apparent ill effects either on their health or on their careers - although, as with any drug, a minority have suffered adverse effects from dependence or psychiatric disturbance (Iverson 2004, p.523).

While critics will point out adverse health effects in cannabis consumers, activists will counter with evidence of the rapid and substantial effects of lifetime 'recreational' tobacco and alcohol use. Thus, cannabis activists will typically purport to have "identified alcohol and tobacco as more harmful than cannabis" (Shiner 2003, p.777). Critics respond, however, by noting the pervasiveness of alcohol and tobacco use in Canadian society and the general unrest that legislating and restricting them would cause. Further, many activists look beyond justifying the leisure aspects of the substance compared to other narcotics and emphasize the medicinal qualities: many advocates recognize the historical place of cannabis as a locally produced herbal remedy (Mukuriya 2004).

Justifying cannabis use through an appraisal of the health costs of the drug compared to other legal narcotics is not the sole argument put forward by those who seek cannabis liberalization. While medicine, leisure and enjoyment are part of the activist's reasons for challenging current drug laws, there are broader institutional concerns linked to their fight. Cannabis activists are fighting against institutions that are embedded in governance: police agencies and anti-narcotics bureaucracies dedicated to the enforcement of drug laws on a local, national, and international scale. Critics of current cannabis law enforcement are fighting for reform for social and political reasons: some feel that cannabis criminalization is sustained by police to ensure funding and to provide them with more enforcement power (Gardner 2004). This is especially important when 
one situates cannabis as part of the greater war on drugs. Many feel that the drug war is simply a product of drug enforcement bureaucracies. Activists realize that these bureaucracies play no small part in re-drafting legislation surrounding cannabis:

There is an increasing albeit sometimes grudging acceptance that cannabis has become part of our culture. The laws proscribing its use have done little to curb the growth of its popularity among the young, and may well have done more harm to young people's lives than the drug itself. Sooner or later one suspects that moves towards the full legalization of cannabis will occur - although for the time being such moves will be thwarted by the monolithic powers of the 'drug warriors' in the USA and the UN International Narcotics Control Board (Iverson 2004, p.523).

The reluctance of narcotics policing agencies to adapt their views on cannabis and cannabis' medicinal and social uses can be explained by the moralizing mantras of the politicians and spokespersons that have developed the stigma surrounding the substance. It is, after all, politicians who have helped develop these institutions for moral and political gain:

Drugs are menacing our society. They're threatening our values and undercutting our institutions. They're killing our children.... Drug trafficking is a threat to our national security.... Let us not forget who we are. Drug abuse is a repudiation of everything America is. The destructiveness and human wreckage mock our heritage (Reagan 1986, pp.1138-39).

In Canada, only $10 \%$ of federal expenditure is on rehabilitation or drug awareness and " $90 \%$ of federal expenditure [is] on supply reduction" (Kiseley 2004, p.156); here, 'reduction' implies the apprehension of producers, dealers, and users. Importantly, narcotics police agencies developed during an era when cannabis was misunderstood and manipulated by moral entrepreneurs such as Canada's Emily Murphy (Giffen et al. 1993) and various American presidents (Shafer 1972, Gardner 2004, StopTheDrugWar 2003). Cannabis activists feel that the drug is simply maintained as criminal to prevent the 
dissolution of embedded drug enforcement institutions that portray cannabis as a serious social evil in order to maintain their budgets (Benoit 2003, The White House 2007).

Regardless of all the other narcotics that enter North American borders through clandestine networks, cannabis enforcement and interdiction in North American society receives a substantial budget. Though activists continually question the necessity of drug enforcement bureaucracies, citing government research into the social and economic costs of the drug war (Kenny and Nolin 2003), those institutions and actors fighting the drug war receive strong support from critics of cannabis liberalization. These critics also make their voices heard in the Canadian cannabis debate.

Critics of cannabis liberalization are a large and politically active group. Critics do not discuss the health consequences of legal narcotics nor do they question the legitimacy or funding costs of the institutions that enforce and prosecute cannabis offenders. While many are quick to dismiss the claims made by cannabis critics, the opinions of the critics are powerful since they help reinforce the existing laws surrounding cannabis. This is essential to the debate surrounding cannabis since reinforcement of the status quo is synonymous with maintaining and strengthening cannabis laws.

Many of those opposing decriminalization perceive cannabis as a gateway to further immoral and/or dangerous behaviour. Preventing drug addiction by eliminating 'gateway' drugs is a powerful argument for those who advocate the maintenance of current cannabis laws. Gateway theory is "commonly credited to the scientific research of [D.B.] Kandel" (Golub and Johnson' 2002, p. 5) who argues that drug users start a downward spiral through seemingly innocuous narcotics: 
Advocates of this perspective derive support by superimposing research findings that youths tend to progress through a specific sequence of substances with other findings of correlations between drug use, crime, violence, unemployment, poverty, family dissolution and other social problems (Golub and Johnson 2002, p.5).

Advocates of gateway theory suggest a positivistic relationship between cannabis use, addiction to 'hard' narcotics, and a life of crime by removing the drug from the context of use on its own. Fear is a simple by-product of this theory and evidence for panics developing in this manner are found in the analyses of the opium crisis in Canada (Giffen et al. 1993) as well as the North American crack 'epidemic' of the late nineteen eighties to early nineties (Reinerman and Levine 1997). Further, fears regarding physical addiction play a strong role with regard to how cannabis conservatives frame policy:

The risk of developing a dependence on cannabis is one of the main arguments in national and international health and social-political discussions concerning cannabis use control policies (Soellner 2005, p. 857).

Gateway theory suggests that the abuse of softer drugs can encourage the use, and subsequent addiction to, harder and more harmful narcotics (Tarter 2006, The White House 2007). Though 'gateway' theory is unpopular and has been dismissed by the Supreme Court of Canada (Erickson and Oscapella 1999, p.316), it still finds merit with conservatives in the cannabis debate since it has been a cornerstone theory for the largest and most vocal supporter of opposition to cannabis liberalization anywhere: American foreign drug policy (Benoit 2003, The White House 2007).

Further, critics of liberalizing cannabis laws argue that cannabis consumed in tandem with alcohol is a cause of many teenage impaired driving deaths (MADD 2003, MADD 2005). Affiliating cannabis with a legal narcotic, namely alcohol, critics have increased the potential harm of the narcotic while completely removing it from the 
context of use on its own. The concerns of parents, and citizens in general, with respect to impaired driving is genuine, however, and few would argue that driving while using cannabis represents safe and ethical behaviour.

There are other health risks, however. Health concerns associated with cannabis smoking and consumption include lung and throat cancer, psychological instability, and reduced sperm count in men (Hall and Solowij 1997, Health Canada 2005, Soellner 2005). Evidence of these concerns is often used in response to the health concerns regarding legal narcotics tabled by cannabis activists. However, there is uncertainty in the medical data, and critics, much like advocates of liberalization who can also rely on uncertain data, rely on "the most probable adverse health effects of cannabis use acknowledging where appropriate the uncertainty that remains" (Hall and Solowij 1997, p. 1611). That is to say, neither group has definitive scientific evidence that can support its cause.

These various concerns about the negative effects of cannabis are propagated by active political groups who feel that Canadian society needs to maintain or reinforce conservative attitudes, values and laws (REAL, OACP 2002). Canada's current Prime Minister has expressed his concern that cannabis is more destructive than alcohol or tobacco, condemning the previous political regime for its decriminalization plans (CBC 2002(2)). Further, the Conservative Party of Canada was vocal against the tabling of the Liberal's Bill C-38 (Canada 2003).

Finding consensus with respect to cannabis in present day Canada is not possible. Canadians will continue to debate the legitimacy or illegitimacy of cannabis laws for many years to come. However, this is not the concern of this thesis. Rather, this thesis 
intends to examine the responses of the judiciary to cannabis in the context of this ongoing and heated debate. After discussing the various elements of the Canadian cannabis debate, discussion focuses on the methodology employed in this research thesis. 


\section{CHAPTER 5: METHODOLOGY}

The focus of this thesis is on the responses of the Canadian judiciary to cannabis cases. In order to examine judicial responses, a multi-method approach was used combining both quantitative and qualitative analyses. First, an analysis of sentencing data was undertaken since this can provide information on what judges have deemed as appropriate sentences for cannabis and other narcotics offenders. Studying sentencing as a judicial act has been done in similar research. As Macdonald et al., point out:

Studies of sentencing outcomes have identified the importance of not just the facts of the case, but how they are perceived by the judges within the broader context of their sentencing philosophy (Macdonald et al. 1999, p.276).

The information garnered through this quantitative analysis was augmented by a qualitative analysis of the explanations that judges provided for their sentences in cannabis cases. In this way, both actual sentencing data and rationales provided by judges for sentences were examined.

\section{Data Sources: Sentencing Data and Case-Law Analysis}

Sentencing data for the quantitative analysis was obtained from the Canadian Centre for Justice Statistics at Statistics Canada. The data set contains all narcotics charges which were brought to court in the index period between and including 1997 to 2003. A seven year index period was chosen, as opposed to a single year, since the longer period is temporally less specific and the statistics produced will not be reflective of a single year. That is to say, the selection of the multi-year period is used to show long term patterns in sentencing practices and to increase the size of the sample available for 
analysis. Further, the seven year index period helps increase the number of cases that can be included in the qualitative case-review sample. This is an important consideration since there are a limited number of cases reported in any given year. Each charge in the quantitative data set was categorized according to the appropriate section of the Controlled Drugs and Substances Act and by Schedule of narcotic. ${ }^{4}$ Thus, a section 4(4) charge for a Schedule II substance would represent an indictable cannabis possession charge, whereas a section 7 charge for a Schedule I substance would represent an indictable charge for the production of cocaine, crack, or opiates. Each record also included information on type of sentence received. Simple recodes were used to include all non-cannabis narcotics offences in one response category, thereby separating them from all cannabis offences and allowing sentences to be compared. The data is weighted by and conforms to Statistics Canada guidelines. The data set includes 158,218 charges. There are no personal identifiers included in the CCJS data, which eliminates any ethical issues.

Utilizing aggregate data, especially data produced by the government, can be problematic:

Official statistics are by no means uniform in their quality or in the political considerations to which they may be responding, and some sources of official statistics are more acceptable than others (Davies 1999, p.143).

Looking critically at the source data used in this thesis, it is important to recognize that these statistics reflect the operation of the existing criminal justice system and, as Davies notes above, all of the factors that influence its operation. On the other hand, these data reflect all cases known to the courts; they do not represent all violations of the criminal code related to drug use, sale, distribution or production. They do, however, represent

\footnotetext{
${ }^{4}$ A copy of Schedule II, Schedule VII, and Schedule VIII are included in Appendix V for reference
} 
cases heard in the criminal court process and they are, therefore, excellent for understanding judicial sentencing practices in narcotics cases.

The qualitative data used in this study was drawn from cannabis case transcripts found in LexisNexis' Quicklaw, an electronic database of case law accessible through academic and government institutions. Cannabis cases that were included in this study were found using Quicklaw's internal search engine. Note that LexisNexis's Quicklaw application does not contain all judgements pertaining to cannabis offences, or for most offences for that matter, and as such does not contain the entire population of cases; this issue is discussed in more detail later in this chapter. After entering "cannabis and sentencing" as the search criteria, the first fifty cases falling in the index period, 1997 to 2003 inclusive, involving a cannabis offence were selected. A purposive sampling method was utilized since LexisNexis does not allow its users to draw a random sample based on time criteria:

Purposive sampling is a sampling method in which elements are chosen based on purpose of the study. Purposive sampling may involve studying the entire population of some limited group (sociology faculty at Columbia) or a subset of a population (Columbia faculty who have won Nobel Prizes). As with other non-probability sampling methods, purposive sampling does not produce a sample that is representative of a larger population, but it can be exactly what is needed in some cases - study of organization, community, or some other clearly defined and relatively limited group (QMSS 2003).

A sample size of fifty was chosen to be large enough to provide some sense of the types of responses emanating from the judiciary while staying small enough to be manageable. Note that there are no 'not-sentenced' or acquitted cases in the case-review sample; due to the selection method and the search criteria, there is no way to include non-sentenced cannabis cases. Further, inclusion of acquitted and not-sentenced cases would require a more complex method. However, since this research is interested in the variety of 
rationales judges provide to explain their sentences, this is not particularly limiting; though it would be useful to hear the remarks of judges who have determined innocence or stayed proceedings.

One of the limitations of this method is that there is no definitive way to ascertain if all cannabis cases are included in the LexisNexis Quicklaw database. It is safe to assume that not all cannabis cases are listed in the database, and this assumption is reinforced by LexisNexis in their disclaimer pertaining to Quicklaw. ${ }^{5}$ These omissions can result in a systematic bias based on how cases are selected for inclusion. Another limitation to the case review lies in the statements from the judges themselves to the cannabis crimes they address: it is possible that a judge can have a strong stance against cannabis trafficking and a lax stance with respect to cannabis possession. This conflates the issues of the cannabis debate and prevents making any distinction in the case-review of the multiple opinions individual judges have towards cannabis. However, since the qualitative data is used here to provide some context for understanding sentencing practices and the responses from judges to specific cannabis crimes, the approach is a useful one.

While the LexisNexis cases identify individual offenders, these cases are in the public domain. As a result, there are no ethics issues involved with their use. A complete list of all cases, year of trial, and province of trial is included in Appendix II.

\footnotetext{
${ }^{5}$ A hyperlink to LexisNexis' Quicklaw disclaimer is provided: http://www.lexisnexis.ca/corporate/disclaimers.php
} 


\section{Research Questions}

The questions examined in the quantitative and qualitative analyses are as follows:

1. What is the distribution of narcotics offences, for cannabis and all other narcotics, in the index period;

2. What types of sentences are being given for the various cannabis offences coming before Canadian courts;

3. How do these sentences compare with those given for similar violations of other drug laws;

4. What types of responses do judges have in sentencing cannabis offenders; and

5. What are the implications of these sentencing practices for the current debate over cannabis laws?

This last question will be dealt with in the conclusions and recommendations chapter at the end of the thesis. These questions are central to contributing to an understanding of the responses of the judiciary to cannabis.

\section{Quantitative Analysis}

Descriptive statistics are used to analyze trends in the sentencing of cannabis offenders for various types of offences. The offences are ranked in the order, from least serious to most serious, that are found in the Controlled Drugs and Substances Act. This ranking also reflects the seriousness rankings these crimes have attributed to them by the criminal justice system, as discussed in the literature: possession of cannabis; trafficking or possession for the purpose of trafficking cannabis; and production of cannabis (CDSA 1997, CCJS 2006). 
With respect to other narcotics, the offences are ranked similarly: general narcotics possession, general narcotics trafficking, and general narcotics production. Note that the importation offence for both cannabis and general narcotics has been omitted. This was done since there is no way to determine what narcotics are imported due to limitations in the CCIS data set. The dispositions are ranked qualitatively in terms of confining the offenders' liberty: incarceration, conditional sentence or sentence served in the community, probation orders, fines, and not sentenced. In the data set, not sentenced is equated with a stay of proceedings, an acquittal, or a judicial dismissal of the Crown's case. In essence, the 'no sentence' label qualifies all cases where a defendant was not found guilty of the charge.

To answer the questions outlined above, frequency distributions were produced to show how judges have sentenced cannabis and narcotics offenders. Chi-square statistics were utilized to investigate the likelihood of relationships between offences and sentences in the CCJS data. Utilizing the chi-square statistic has benefits for the social sciences:

This test assumes only that the variables are measured at the nominal level (the lowest level of measurement) and, because it is a nonparametric, or "distribution free" test, it requires no assumption at all about the shape of the population or sampling distribution (Healey 2001, p.268).

All variables included were nominal in nature; hence the chi-square test is ideally suited to this study. The chi-square statistic helps to determine if relationships exist between two variables. For example, when the research compares cannabis possession charges to type of sentence received, the chi-square statistic identifies the likelihood that the relationships are not due to chance. 
In addition to the chi-square statistic, a measure of strength of association was applied. The Cramer's V statistic was used since it is suited to tables which are larger than two by two and which utilize nominal variables. Cramer's V"can be interpreted as an index that measures the strength of association between two variables" (Healey 2001, p.322). Cramer's $V$ allows for an understanding of the relative strength of an association with values of 0 (being no relationship) and 1 (being complete relationship).

The quantitative analysis includes all narcotics offence sentences in order to provide detail regarding the overall counts and rates of drug indictments in Canada's courts and to contrast them against cannabis sentencing practices.

\section{Qualitative Case Review}

As discussed earlier, a purposive sample of fifty cannabis cases was drawn from the LexisNexis electronic database. A review of statements pertaining to guilty cannabis offenders by members of the judiciary was conducted using these cases. This review was undertaken in order to explore the rationales judges give for their decisions in cannabis cases as well as to investigate the prevalence of the principles of sentencing and limitations to judicial discretion as outlined in the literature review. This analysis is based on cannabis cases in which sentences were given in Provincial and Superior courts or, in some cases, the Supreme Court of Canada. Each case falls in the index period, 1997 to 2003 , in order to be consistent with the dates included in the quantitative data set. In the sample, $28 \%(n=14)$ of cases were appeal cases where three judges were involved in deliberating the cannabis offence in court. The remainder $(n=36)$ were judgements 
given by a single judge. Jurisdiction of judgement, that is, where the case was tried, is included in Appendix IV.

In the literature review various sentencing principles and limitations were identified in relation to the exercise of judicial discretion. The issues discussed in the literature are as follows:

- deterrence - specific and general;

- concern for the community;

- remarks regarding the moral nature of the crime or criminal;

- judicial remarks regarding discretion;

- direct mention of the cannabis debate; and

- mention of the proportionality/perceived harm of the crime(s) committed.

These themes were derived from the review of the literature. They reflect the types of rationalizations or explanations that judges may give for their sentencing decisions. They may also reflect the way judges view existing laws and punishments. Further, if judges highlight these issues and principles of sentencing, it may reflect a harsher or stronger sentencing attitude when punishing cannabis offenders.

Each case was analyzed according to the themes identified above. This analysis was performed to ascertain how prevalent the principles of sentencing were in the judges decisions. Evidence was also sought for the impact of the cannabis debate on judicial decision making.

A careful examination was made of each of the cases, and instances of the themes identified above were recorded. For example, if a judge referred to the 'evil nature' of a crime, this was recorded as an instance of morality being used as a rationale for the 
sentence given. Note that not all themes are present in all the cases sampled; in fact, it is not necessary for any theme to be present. However, the appearance of these themes may reflect the principles of sentencing or the theoretical and practical limitations to judicial discretion. This, in turn, may have an effect on the types of responses judges have towards cannabis offences and offenders in Canada's courts.

Particular attention was paid in this analysis to the rationales provided by the judges for their sentencing decisions. Key quotes from presiding judges were drawn from the cannabis cases to illustrate the range of responses that were made. As each case was read, quotes were recorded in which judges directly respond to the cannabis offender and/or the offence in question. These quotes were picked if they referenced to the principles of sentencing, such as discretion and deterrence or proportionality and harm of the crime committed, or if they overtly referenced the cannabis debate in Canada. These quotes were then sorted into three nominal categories, based on the type of response noted. These categories reflect, broadly, the differing 'sides' of the cannabis debate: those supporting or reinforcing the law, those who question the law or are sympathetic to cannabis transgressions, and those in between. The first category reflects support for the law and contains responses that acknowledge the criminality of cannabis offences and the need to punish cannabis offenders. The next category represents those judges whose statements appear to show sympathy for the offenders or question the necessity of cannabis laws. These quotes represent opposing views of those in the first category. Finally, the third category represents quotes from judges whose statements show that cannabis is neither a serious offence nor a harmless one. These quotes are neutral with respect to a response to cannabis, but explicitly so. 


\section{Limitations}

There are a number of limitations to this study that require discussion. First, the data does not provide ranges for particular types of sentences. That is to say, only the type of sentence awarded is reported, not the length imposed. While the latter information would be useful, it is beyond the scope of the present study. Also, there are no geographic identifiers in the aggregate data making a regional analysis impossible. Finally, the data does not include information regarding how many judges are involved. While these considerations are important, the analysis presented here does provide some important insights into sentencing practices in cannabis and other narcotics cases. 


\section{CHAPTER 6: FINDINGS}

\section{Descriptive Context of Narcotics Convictions 1997-2003}

In the following discussion, the findings follow the order of the research questions outlined above. The analysis starts by describing the aggregate data. This is followed by a discussion of those who were not sentenced; this includes those found not guilty, acquitted, or whose cases were dismissed for other reasons.

The first step in the analysis compares cannabis offences to all narcotics offences in the index period of $1997-2003(\mathrm{n}=158,218)$. This shows how the proportion and type of cannabis offences compare to all other narcotics offences in the index period. Table 1 displays the frequency distributions for all types of offences in the data set:

Table 1.

Distribution of All Charges in Index Period

\begin{tabular}{cll}
\hline Offence Type & $\mathrm{n}$ & $\%$ \\
\hline General Possession & 82446 & $52.0 \%$ \\
Cannabis Possession & 8018 & $5.0 \%$ \\
General Trafficking & 57005 & $36.0 \%$ \\
Cannabis Trafficking & 2051 & $1.0 \%$ \\
General Production & 8089 & $5.0 \%$ \\
Cannabis Production & 609 & $0.4 \%$ \\
\hline Total & 158,218 & $100 \%$ \\
\hline
\end{tabular}


As can be seen in Table 1 there were 158,218 narcotics charges over the seven year period. Of these, over $50 \%(n=82,446)$ were general, non-cannabis related, possession charges. Cannabis possession represents $5 \%(\mathrm{n}=8018)$ of all charges, whereas cannabis trafficking and production account for less than $2 \%(n=2660)$ combined. Based on the data, cannabis represents less than $7 \%(n=10,678)$ of all drug-related charges. This is noteworthy since there is strong message regarding cannabis from cannabis conservatives about the level of cannabis use, yet comparatively few formal charges were found in the index period. Further, this distribution may influence responses from the judiciary since cannabis is not as common in our courts as other, more harmful narcotics.

This research considered whether there had been any changes in the number of charges over the index period in addition to the proportion of charges that were cannabis related. This is important because an increase or decrease in charges over time might influence judicial decisions. Table 2 presents the distribution of the counts of offence charges over the 7 year index period. These data show that there is a statistically significant relationship which produced a Chi-squared of $\chi^{2}(36, \mathrm{n}=158,218)=2602.80$, $\mathrm{p}<.0001$. Though there is a statistical relationship it is due, in part, to the large number of cases. So, to develop a clearer understanding a $c r v$ was produced - it yielded a $c r v(30)=$ $0.057, \mathrm{p} .<.0001$. This indicates no association and no direction between the variables of year and offence type: 


\section{Table 2.}

Offence Type Counts by Year of Charge

\section{Offence Type}

Year

of Cannabis General Cannabis General Cannabis General

Charge

Possession Possession Trafficking

Trafficking Production Production Total

$199757^{*}$

1144

12

476

2

50

1741

1998

640

10066

79

5414

50

708

16957

1999

$990 \quad 11657$

11657

217

6376

58

822

20120

2000

1052

13190

324

6888

70

751

22275

2001

1745

17037

456

12006

111

2021

33386

$\underline{2002}$

1959

16314

521

12865

165

2021

33845

$\underline{2003}$

1575

13038

432

12980

153

1716

29894

Total

8018

82446

2051

57005

609

* Low charges in 1997 can be attributed to the transformation of legislation from the older Narcotics Control Act to the newer Controlled Drugs and Substances Act. Though the figures are low, they are still representative counts of the types of offences and worth including in this anatysis. 
All charge categories steadily increased following the first year in the set. This increase is generally continuous among the charges, save for production, until 2003 when all but general trafficking drop.

With respect to cannabis charges, there are large increases in the beginning of the index with cannabis possession increasing $206 \%$ between 1998 and 2002 . This is in contrast to a $62 \%$ increase for general narcotics possession charges. Further, cannabis trafficking charges increased 559\% while general narcotics trafficking witnessed a $138 \%$ increase in charge rates between 1998 and 2002. Cannabis production charges increased $230 \%$ and general production increased $185 \%$ in this same period. Generally, charges increased $76 \%$ over the bulk of the index period. However, it is noticeable that cannabis offence charges increased more dramatically than all other general narcotics offence charges. Cannabis became more and more the focus of law enforcement and prosecution in the index data. The effects of this increase are discussed later in this chapter.

While cannabis has proven to be costly for law enforcement and the courts (CID 2005, Kenny and Nolin 2003), it is remarkable that cannabis accounts for less than $7 \%$ (n $=10,678)$ of all cases in the index period $(n=158,218)$. It is interesting that so much attention has been focused on a relatively small proportion of cases in our court system. This is noted since charges identified as cannabis possession represent $5 \%(f=8018)$ of all Controlled Drugs and Substances indicted charges during the index period. While cannabis is often reported by law enforcement, it is apparent from the data that cannabis offenders are rarely formally charged and brought to court.

Next we compared the ratios of cannabis offences rate within the cannabis offence category - this provided another sense of the types of cannabis offences the judges were 
seeing. Table 3 provides the frequency distribution of cannabis convictions by offence type $(\mathrm{n}=10,678)$ :

\section{Table 3.}

Cannabis Charges by Type of Offence

\begin{tabular}{lll}
\hline & $\mathrm{n}$ & $\%$ \\
\hline Cannabis Possession & 8018 & $75 \%$ \\
Cannabis Trafficking & 2051 & $19 \%$ \\
Cannabis Production & 609 & $6 \%$ \\
\hline Total & 10678 & $100 \%$ \\
\hline
\end{tabular}

Cannabis possession represents three quarters of all cannabis charges in the index period. This indicates that there are almost four cannabis possession charges for every one cannabis trafficking charge. Production of cannabis charges represent less than $6 \%(\mathrm{n}=$ 609) of cannabis charges. Regardless of the low counts of cannabis charges in the courts, increases, as discussed above, in the rates for all offences are seen in the index period. This increase may have an effect on the responses of judges to cannabis offenders since their sentencing practices may become altered in the presence of an offence which was once an uncommon occurrence but became more frequent. As well, the prevalence of cannabis possession charges may have an impact on how judges respond since possession is considered a less-aggravated offence by criminal justice rankings as well as by many members of society, including law enforcement officers. In turn, lower trafficking and production counts may result in stronger sentencing responses. This result will be 
discussed in the following sections where different types of cannabis offences are related to sentencing practices.

\section{All Narcotics Offences and those 'Not Sentenced'}

Another dimension of offences that is important is how many charges for the various types of offences did not result in a sentence. Those who were not sentenced are defined as those cases which were withdrawn, dismissed, had a stay of proceedings, or received an absolute discharge. Note that they do not include conditional discharge or suspended sentences; the data lacked the detail necessary for distinguishing these categories. These counts represent those cases that were found not guilty, acquitted, or dismissed for various reasons. Table 3.1 below displays the counts of offences not sentenced. Note that in all other tables following Table 3.1, not sentenced counts were omitted since there is no way to verify if the charges were specifically acquitted or stayed by a judge.

Nearly half of all offence types received no sentence, save for general trafficking and both production offences. Cannabis possession charges witnessed only $51 \%$ conviction efficiency while $56 \%$ of general narcotics possession charges were convicted. An interesting disparity exists between cannabis trafficking and general narcotics trafficking: $53 \%$ of cannabis traffickers were found guilty while only $43 \%$ of general narcotics traffickers were convicted. Further, both production offences, cannabis and general, had high conviction ratios, with $69 \%$ and $68 \%$ respectively. These higher conviction ratios for production offences may indicate that the judges, as well as prosecutors and police officers, take production offences more seriously due to their 
standing as aggravated offences; more discussion regarding sentencing will be provided

later in this chapter.

\section{Table 3.1}

Not Sentenced by Type of Narcotics Offence

Cannabis Possession

Count

$\%$ within offence type

General Possession

Count

$\%$ within offence type

Cannabis Trafficking

Count

$\%$ within offence type

General Trafficking

Count

$\%$ within offence type

Cannabis Production

Count

$\%$ within offence type

General Production

Count

2626

$\%$ within offence type

Not Sentenced

3924

$49 \%$

36107

$44 \%$

962

$47 \%$

$57 \%$

191

$31 \%$

$32 \%$

Total

Count

76049

$\%$ of all charges

$48 \%$ 
While we can't infer a great deal from the not sentenced counts, it is nevertheless interesting to see how effective prosecutors and the police are in presenting cannabis and other narcotics cases for trial. Further, it is interesting to note that drug offences, notably cannabis and general trafficking, are only likely to receive a conviction half the time, especially when there are strong anti-narcotics statutes and embedded anti-narcotics law enforcement units in Canada.

\section{Cannabis Possession, General Narcotics Possession and Disposition Received}

Relating cannabis dispositions to corresponding general narcotics dispositions helps us understand the practices and nuances related to narcotics legislation in the criminal court system. Table 4 compares cannabis possession sentences with general narcotics sentences. A statistical analysis of the relationship between type of offence and type of sentence produced a Chi squared of $\chi^{2}(4, n=50,433), p<.0001=95.70$. The assessment of strength of association yielded a $\mathrm{crv}(4)=.04, \mathrm{p} .<.0001$, indicating that while a relationship exists between these variables, the strength of the association is negligible.

The data in Table 4 indicates that sentences are not typically oriented towards incarceration; rather they appear to be more moderate for simple possession of cannabis. The most dominant sentence type for cannabis possession was a fine, given in $57 \%(\mathrm{n}=$ 2318) of all cannabis charges. This is similar to general possession which showed that $55 \%(n=25471)$ of those found guilty received a fine. The next most dominant sentence for both cannabis possession and general possession offences was probation, representing, respectively, $19 \%(n=776)$ and $23 \%(n=10575)$ of cases receiving this 
sentence. Only $11 \%(n=466)$ of those found guilty of cannabis possession and $13 \%(n=$ 5841 ) of those found guilty of general narcotics possession were incarcerated. It is significant that fines are the dominant mode of sentencing for all possession offences, especially when looking back at the principles of sentencing such as specific and general deterrence, as well as the concept of proportionality.

\section{Table 4.}

Cannabis Possession, General Possession and Disposition Type

Disposition Offence Type

\begin{tabular}{|c|c|c|}
\hline & Cannabis Possession & General Possession \\
\hline \multicolumn{3}{|l|}{ Incarceration } \\
\hline Count & 466 & 5841 \\
\hline$\%$ within offence type & $11 \%$ & $13 \%$ \\
\hline \multicolumn{3}{|l|}{ Conditional Sentence } \\
\hline Count & 25 & 439 \\
\hline$\%$ within offence type & $1 \%$ & $1 \%$ \\
\hline \multicolumn{3}{|l|}{ Probation } \\
\hline Count & 776 & 10575 \\
\hline$\%$ within offence type & $19 \%$ & $23 \%$ \\
\hline \multicolumn{3}{|l|}{ Fine } \\
\hline Count & 2318 & 25471 \\
\hline$\%$ within offence type & $57 \%$ & $55 \%$ \\
\hline \multicolumn{3}{|l|}{ Other } \\
\hline Count & 509 & 4013 \\
\hline$\%$ within offence type & $12 \%$ & $9 \%$ \\
\hline \multicolumn{3}{|l|}{ Total } \\
\hline Count & 4094 & 46339 \\
\hline$\%$ within offence type & $100 \%$ & $100 \%$ \\
\hline
\end{tabular}


However, returning to the sentencing maximums where fines and incarceration are indicated for cannabis possession offences, it would appear that fines are sufficient and preferable to incarceration sentences by the judiciary. Further, it appears that judges deem that monetary punishment is both commensurate to the crime of possession of cannabis, and serves the need for specific and general deterrence. Perhaps this result is indicative of differing responses to cannabis in the courts.

Contrasted against other narcotics, however, there is no strong variation in sentencing practices which would suggest that judges differentiate between cannabis and other narcotics when sentencing for possession offences. The more important finding is that a less serious sentence of a fine is deemed appropriate by judges more than half the time for those offenders found guilty of possessing illegal narcotics.

\section{Cannabis Trafficking, General Narcotics Trafficking and Disposition Received}

Looking at the aggravated offence of trafficking, Table 5 below compares cannabis trafficking sentences to general narcotics trafficking sentences. The Table produced a chi-squared of $\chi^{2}(4, \mathrm{n}=25855), \mathrm{p}<.0001=148.91$ as well as $\operatorname{crv}(4)=.08$, $\mathrm{p}<.0001$. This indicates that while there is an association between the variables, it is very weak.

Illegal trafficking of cannabis represents a small portion of all narcotics charges, representing $1 \%(n=2051)$ of all cases, and only $19 \%$ of all cannabis cases in the aggregated data. However, there are differences in sentencing patterns for offenders who have been found guilty of trafficking. These differences will be discussed below. It is possible that these differences are accounted for by the perception that trafficking of 
harder narcotics, other than cannabis, is an aggravated offence with a strong social and moral stigma attached to the practice.

In terms of sentences received, $39 \%(n=422)$ of cannabis traffickers were sentenced to incarceration while general narcotics trafficking offences saw $54 \%$ (n $=13255$ ) of charges awarded incarceration. Cannabis traffickers, it would appear, are less likely to receive an incarceration sentence compared to other narcotics dealers; this disparity may be evidence of a response from the judiciary regarding the severity of trafficking other narcotics compared to the trafficking of a less harmful substance. The next most dominant sentence for cannabis and general narcotics traffickers was a conditional sentence order for $22 \%$ of both cannabis and general narcotics traffickers. Probation and fine ratios were similar for cannabis and general trafficking offences, representing, roughly, $18 \%$ and $11 \%$ respectively. General narcotics trafficking received more aggravated sentences compared to those given for cannabis trafficking. Returning to the percent increase over the index period, it is interesting to note that even though cannabis trafficking charges increased $559 \%$ during the bulk of the index period, incarceration of cannabis offenders by judges is $15 \%$ lower than that for general narcotics trafficking. 
Table 5.

Cannabis Trafficking, General Trafficking and Disposition Type

\begin{tabular}{|c|c|c|}
\hline & \multicolumn{2}{|c|}{ Offence Type } \\
\hline & Cannabis Trafficking & General Trafficking \\
\hline \multicolumn{3}{|l|}{ Incarceration } \\
\hline Count & 422 & 13255 \\
\hline$\%$ within offence type & $39 \%$ & $54 \%$ \\
\hline \multicolumn{3}{|l|}{ Conditional Sentence } \\
\hline Count & 241 & 5557 \\
\hline$\%$ within offence type & $22 \%$ & $22 \%$ \\
\hline \multicolumn{3}{|l|}{ Probation } \\
\hline Count & 188 & 2763 \\
\hline$\%$ within offence type & $17 \%$ & $11 \%$ \\
\hline \multicolumn{3}{|l|}{$\underline{\text { Fine }}$} \\
\hline Count & 211 & 2645 \\
\hline$\%$ within offence type & $19 \%$ & $11 \%$ \\
\hline \multicolumn{3}{|l|}{ Other } \\
\hline Count & 27 & 546 \\
\hline$\%$ within offence type & $3 \%$ & $2 \%$ \\
\hline \multicolumn{3}{|l|}{ Total } \\
\hline Count & 1089 & 24766 \\
\hline$\%$ within offence type & $100 \%$ & $100 \%$ \\
\hline
\end{tabular}

Sentencing counts shows that trafficking is considered an aggravated offence since incarceration sentences dominate both cannabis and general narcotics. However, there is a diversity of sentences for both categories of traffickers. This diversity is generally contiguous between the two types of trafficking offences, save for the 
difference in incarceration ratios and the higher likelihood of probation and fine sentences for cannabis traffickers as opposed to general narcotics dealers. If the principles of deterrence and proportionality are applied, is it possible that there is a lack of consensus over the severity of trafficking specific varieties of narcotics? While sentencing counts show that the judiciary typically utilizes incarceration for traffickers, the odds are good that many judges will apply a less serious sentence to a cannabis trafficking offence rather than a general narcotics trafficking offence, suggesting that judges have differing opinions on what is an appropriate sentence in these cases. This differs considerably from the findings regarding the use of custody in simple possession cases. Further, returning to the sentencing maximums outlined above, judges have sentenced some cannabis traffickers to incarceration as suggested by the sentencing maximums, but many more have been awarded conditional sentences or fines and probation for these offences. The key difference here is that judges are more likely to provide aggravated sentences for general narcotics traffickers compared to cannabis traffickers.

\section{Cannabis Production, General Narcotics Production and Disposition Received}

While many illicit narcotics are produced outside of Canada, crack, methamphetamine and cannabis are all produced in Canada for local distribution as well as for export. Table 6 below shows the trends in sentencing for cannabis growers and chemists who mix other illicit narcotics. A statistical analysis produced a chi-square statistic $\chi^{2}(4, \mathrm{n}=5881), \mathrm{p}<.01=14.23$ as well as a $c r v(4)=.05, \mathrm{p} .<.01$ indicating that while an association exists between these variables, it is extremely weak. 
Production is the most aggravated of all the cannabis offences. This is reflected in sentencing maximums, where the maximum sentence for cannabis production is 7 years incarceration, and the maximum sentence for production of non-cannabis narcotics is a possible life sentence in incarceration.

Sentence types awarded for cannabis growers varied compared to those given for general narcotics producers. The most common sentence awarded for producers of both cannabis and general narcotics was a conditional sentence order given to $30 \%$ and $39 \%$ respectively. The next most common sentence awarded for both offences was a fine given to $27 \%$ of cannabis growers and $25 \%$ of general narcotics producers. This was followed by incarceration, where a disparity is noted; $26 \%$ of cannabis growers received incarceration compared to only $21 \%$ of general narcotics producers. While the difference is not substantial, it is noteworthy since the production of other narcotics is identified as a more serious offence in the sentencing maximums and by law enforcement officials. However, since there was $230 \%$ increase in cannabis production charges in the index period, it could be inferred that judges were responding to a growing problem in the criminal courts.

It is clear from the results presented in Table 6 that there is a division in sentencing practices pertaining to cannabis production. Similarities in sentencing for both cannabis producers and general narcotics producers in the index period suggests that judges respond fairly similarly to both types of offences, though the presence of roughly $26 \%$ of both offences receiving a fine is of note since production is considered a serious offence. Perhaps the variety of sentences awarded for cannabis production, and general narcotics production, is a good indication that not all judges respond to the severity of the 
crime in the same way. Continuing, perhaps some feel that some production crimes, such as mixing one's own crack for personal use or growing three cannabis plants in the basement closet, are insignificant crimes in comparison to all the other drug production crimes.

Table 6.

Cannabis Production, General Production and Disposition Type

\begin{tabular}{|c|c|c|}
\hline & \multicolumn{2}{|c|}{ Offence Type } \\
\hline & Cannabis Production & General Production \\
\hline \multicolumn{3}{|l|}{ Incarceration } \\
\hline \multirow{2}{*}{$\begin{array}{l}\text { Count } \\
\% \text { within offence type }\end{array}$} & 107 & 1183 \\
\hline & $26 \%$ & $21 \%$ \\
\hline \multicolumn{3}{|l|}{ Conditional Sentence } \\
\hline \multirow{2}{*}{$\begin{array}{l}\text { Count } \\
\% \text { within offence type }\end{array}$} & 128 & 2130 \\
\hline & $30 \%$ & $39 \%$ \\
\hline \multicolumn{3}{|l|}{ Probation } \\
\hline \multirow{2}{*}{$\begin{array}{l}\text { Count } \\
\% \text { within offence type }\end{array}$} & 65 & 700 \\
\hline & $16 \%$ & $13 \%$ \\
\hline \multicolumn{3}{|l|}{ Fine } \\
\hline \multirow{2}{*}{$\begin{array}{l}\text { Count } \\
\% \text { within offence type }\end{array}$} & 114 & 1358 \\
\hline & $27 \%$ & $25 \%$ \\
\hline \multicolumn{3}{|l|}{ Other } \\
\hline \multirow{2}{*}{$\begin{array}{l}\text { Count } \\
\% \text { within offence type }\end{array}$} & 4 & 92 \\
\hline & $1 \%$ & $2 \%$ \\
\hline \multicolumn{3}{|l|}{ Total } \\
\hline Count & 418 & 5463 \\
\hline$\%$ within offence type & $100 \%$ & $100 \%$ \\
\hline
\end{tabular}

In looking at the sentencing data, it is interesting to note that while cannabis offences represent less than a tenth of the total charges in the index period, cannabis 
charges increased, proportionally, much faster than general narcotics charges. This is important since it shows that Canada's judges were exposed to more and more cannabis offences throughout the index period. Compared to general narcotics offending, which increased at a fraction of the rate cannabis offending, the perception of cannabis as a growing problem may have had an influence on judicial practices with respect to cannabis cases. However, it is interesting to note, even with large increases in the frequency of cannabis offences, sentencing practices were relatively stable in their heterogeneity.

While there are many instances where sentencing maximums sentence types are followed for possession and production offences, there are just as many where they were not. Further, for all types of drug offences, save general narcotics trafficking, there is no uniformity or regularity in sentencing: Canada's judiciary awards a variety of sentences in narcotics cases, and only in a specific instance, such as general narcotics trafficking, do they follow sentencing maximum sentence types more than half the time. This lack of consistency with respect to the existing legislation and the sentencing maximums lends weight to the argument that judges craft their own responses using their discretionary power. Why these sentencing patterns exist is unexplained, however a look at case-law and the verbatim explanations of judges for the sentences they imposed in cannabis cases will provide some insight on this issue.

\section{A Qualitative Analysis of Cannabis Cases}

In this section the results of the qualitative analysis of cannabis cases are presented. As noted above, this analysis was based on a review of 50 cannabis cases 
appearing in the LexisNexis data base. The methodology included reviewing each of these cases for evidence of explanations or rationales for the sentences given to cannabis offenders. Evidence was sought of the application of the sentencing principles discussed in the literature, as well as reference to the cannabis debate. Table 7 displays the data with respect to the specific themes found in the case review. For example, if a judge mentioned the need for general deterrence or discussed the cannabis debate, this was recorded as such. Note that a theme was only flagged once, regardless of how many times it was mentioned in the case. Table 7 displays the counts of the themes found in the caselaw review.

Of note, less than half the cases coded cited specific deterrence as a concern, while just under two thirds cited both the principles of general deterrence and concern for the community. Further, proportionality of sentence to the crimes committed was only mentioned in under a third of all coded cases. While morality was only mentioned in 9 cases $(16 \%)$, it is noteworthy that nearly one in five of the cases had a judge relating drug offences to moral constructs as outlined in the theory chapter. 


\section{Table 7.}

\section{Distribution of Sentencing and Judicial Discretion Themes}

\section{Theme Present}

\begin{tabular}{lcc} 
& $\begin{array}{c}\text { Number of cases in which } \\
\text { theme present }\end{array}$ & $\begin{array}{c}\% \text { of cases in which } \\
\text { theme present }\end{array}$ \\
\hline General Deterrence & 32 & $64 \%$ \\
$\begin{array}{l}\text { Social/Community } \\
\text { Concerns }\end{array}$ & 30 & $60 \%$ \\
$\begin{array}{l}\text { Specific Deterrence } \\
\text { Proportionality/Harm }\end{array}$ & 22 & $32 \%$ \\
Moral Nature of Crime & 16 & $16 \%$ \\
$\begin{array}{l}\text { Mention of Cannabis } \\
\text { Debate }\end{array}$ & 9 & $10 \%$ \\
\hline
\end{tabular}

Note. $\mathrm{n}=50$

It is important to note that judges cite legal, moral, and social justifications for punishing those who transgress the law. Further, it is possible that the adherence to the principles of sentencing may have an effect on what types of sentences judges give. In the next section, the discussion expands on the qualitative case review and examples are provided of how these principles are used. 


\section{Responses to Cannabis: Discussion of the Data Derived From the Case Review}

It has been shown that sentencing of cannabis offenders and to some extent all narcotics offenders is a diverse and multi-faceted practice. While the quantitative analysis shows the range of sentence outcomes, actual responses from the judiciary add texture and nuance to the statistical analysis of sentencing practices. Comments by judges who have deliberated in cannabis cases in Canadian courtrooms show a variety of opinions regarding the substance. Statements range from declarations of shock and outrage at the offences (e.g., R. v. Gordon [1997], R. v. A.A.W. [1997]) to discussions of the nature of the law. For example, some judges suggest that the law may not accurately reflect the average Canadian's position with respect to cannabis (e.g.., R. v. Malmo-Levine [2003], R. v. Wey [1999], R. v. Krieger [1998]). These positions are apparent when judges show support for cannabis laws or anger at the prevalence of cannabis offences in their courtrooms.

Statements expressing outrage and shock show that, when confronting cannabis offences, some judges feel the sections of the Controlled Drugs and Substances Act are indeed valid and suited to the society which they regulate. The following quote is an example of this stance by a sentencing judge in a cannabis trial:

Those who engage or assist in the distribution of drugs commit a most serious offence. Such activity is reprehensible and justifiably warrants the anger and revulsion of responsible members of society $(R . v$. Gordon [1997]).

Note that the sentencing judge in $R v$. Gordon [1997] responds to narcotics as though they are all similar, making little differentiation between the offending narcotic, cannabis, 
and other illicit substances. This lack of differentiation is also found in a general statement related to the trafficking of cannabis:

Those who contribute to the availability of unlawful drugs on our streets and in our schools are engaged in a commercial enterprise often inextricably linked to consequential criminality and other social evils (R. v. A.A.W. [1997]).

However, another judge identifies what the perceived social effects of cannabis are, and builds discussion around them; note the language pertaining to addiction and the consequences of this that are attributed to the user:

The use of marihuana is a vice that is indulged in by many people in this community. In almost all cases of serious juvenile crime the predisposition reports that I have read show that the young offender is addicted to marihuana and, probably for that reason, is lazy and unwilling to be a conscientious student, with ultimately disastrous consequences for his or her career and social life. I do not overlook the fact that in this case there is no evidence that the Accused sold marihuana to children, but adults who smoke marihuana set the example that children follow ( $R$. v Ross [1998]).

Sentencing practices of some judges follow the recommendations made for sentencing by Parliament; namely, judges will punish with the principles of sentencing as a guide. The themes of general and specific deterrence (R. v. Lambe [2003], R. v. Phan [2002], R. v. Holder [1998]) were used as justifications for imposing aggravated sentences, such as incarceration or long term conditional sentence orders. An example of these principles in practice provides context, where a trial judge explains why incarceration is preferable to a conditional sentence or house arrest sentence order:

Protection of the public is my primary goal in sentencing him for these offences. Individual and general deterrence have been stressed to achieve that goal and that will not happen if I permit [the defendant] to serve his sentence in the community (R. v. Lambe [2003]). 
An excellent example of the reasons used for giving long penal sentences is outlined in $R$. v. Cyr [1997], where the convicted offender attempts to appeal his nine year incarceration sentence for conspiring to traffic large amounts of cannabis. The appeal was allowed, and the sentence reduced to seven years incarceration, though the analysis of the sentencing judge's motives by an appellate judge is telling:

The judge's opening remarks in sentencing these two men laid emphasis upon the seriousness of their offences, the magnitude of the value of the narcotics, the fact that the brothers had been engaged by the ringleaders of the conspiracy and that one was the captain and another a crew member in the ocean-going vessel used for the importation of the drugs. While acknowledging that neither had a criminal record relevant to their offences as well as their pleas of guilty and probable remorse, he nonetheless indicated that public protection was a dominant consideration and that the public was entitled to be safeguarded against persons bringing drugs into society where they will be consumed by children and others "who may not have the strength of character to resist them" (R. v. Cyr [1997]).

Concern for community and harm prevention for society in general, as shown above, can be used to reinforce long aggravated sentences, such as incarceration or conditional sentence orders, for cannabis offenders. Further, judicial remarks outlining the nature of the offence and the social consequences of narcotics offences show that cannabis is taken very seriously by many members of the bench regardless of the socio-legal debate surrounding cannabis. However, there are other comments, made when addressing and sentencing cannabis offenders, which suggest that cannabis crimes are less serious in the minds of the judges than the legislation and law enforcement make them out to be.

While some judges see cannabis offences as in need of punishment and the acts of possession, trafficking, and production as necessarily criminal, others do not paint all cannabis offenders with the same brush. There does exist, based on the qualitative review, a variety of opinions and responses to cannabis emanating from the judiciary; 
evidence of more responses is provided in the following paragraphs. Further, there is specific evidence to show that there is some confusion surrounding what constitutes an appropriate response to cannabis and cannabis legislation.

The case review revealed that some judges simply aren't sure of how to proceed. Some statements and cases leave the impression that the sentences given vary so much because the legislation and sentencing maximums, as well as precedents and case-law, are ambiguous. This lack of clarity is exemplified by the sentencing judge in $R . v$. Shacklock [2000]:

I start out by noting that sentencing is not a science. In saying that I point out that you cannot necessarily compare a disposition in one case to another and say the facts are identical and, therefore, the sentences should be the same. The Court must be responsive in terms of recognizing the objectives that must be met in terms of sentencing. The Court, especially the trial Courts, must be responsive to what the legislators say and to what the superior Courts say in decisions ( $R v$. Shacklock [2000J).

This last quote gives weight to the necessary nature of judicial discretion; judges, being different individuals of varying opinion, cannot assume a standard or model exists in sentencing. Instead, they gauge each case on its merits as it arrives before the courts using the available measures, whether they are the principles of sentencing or case law. Another example of this reliance on the principles of sentencing is given by a judge in $R$ v. Patryluk [2002]:

In addition, we have to pay attention to the objectives of sentencing, again as laid down by Parliament, including not only the objectives of rehabilitation and so on, but as well as the objectives of deterrence and denunciation. Generally speaking, this means that sentences must also be geared to deterring the offender, as well as others, from committing crime, particularly crimes of like-kind, and to denouncing the conduct giving rise to the crimes (R. v. Patryluk [2002]). 
If sentencing is case based, yet limited to the general practices of sentencing found in case law and the restrictions set forth in the sentencing maximums, it is interesting to see how some judges respond to what can seem to be overwhelming options for offences whose severity and social harm are heavily debated:

There are so many differing sentences for marihuana offences in this Province that it cannot be said that there is any common judicial opinion as to what is the right thing to do (R.v. Dean [2002J).

Further, there are opinions which do not cite confusion, which do not recognize the necessity for punishing cannabis offenders, but which offer insights suggesting that not all members of the judiciary are prohibitionist, confused, or simply value neutral with respect to Canada's cannabis debate.

Moreover, while judges are capable of practicing discretion, they are restrained by their professional duty from overtly engaging in lawmaking. Judges who have voiced their opinions regarding cannabis, through sentencing practices and statements, make it clear that they leave the construction and adaptation of law to Parliament. That is not to say that judges cannot be sympathetic and provide less aggravated responses to cannabis than their peers who disapprove of all cannabis and drug offences. A good example of this last point can be found in the remarks of Justice Deschamps of the Supreme Court of Canada:

Canadian society is changing. Its knowledge base is growing, and its morals are evolving. Even if it was once the case, and in my view it never was, the prohibition against cannabis is no longer defensible. My analysis leads me to conclude that the little harm caused by marijuana casts doubt on the appropriateness of state intervention in this case. When I weigh prohibition against, first, other available methods for countering the harm that marihuana use presents and, second, the problems caused by marihuana use, I must conclude that the legislation is inconsistent $(R . v$. Malmo-Levine/Caine [2003]). 
This attitude is noteworthy since it comes from a Supreme Court Justice. However, note that the Justice does not say the legislation is wrong, rather that it is 'inconsistent'. Perhaps the limits to judicial discretion play a powerful role in repressing judicial activism. However, other judges make remarks similar to Justice Deschamp's by providing statements which seem supportive of those who question laws the judges themselves are forced to uphold. This is exemplified in R. v. Saunders [1998], where the theme of social morality once again makes an appearance. While the judge's sarcasm is noted, there is a sense that the judge does not find the offender's behaviour wholly criminal compared to the stronger themes noted earlier:

This court passes no moral judgement, but it must pass legal judgement. Mr. Saunders, you may respect the laws as they relate to possession and use of marijuana, or you may think that they are nonsense... If there is a law which so offends your conscience that you feel compelled to openly and civilly disobey that law, then you may, as was Ghandi, be worthy of respect $(R$. $v$. Saunders [1998]).

More sympathetic evidence is shown when a judge presiding over a cannabis case directly questions prosecutorial demands for tough sentences, perhaps finding a middle ground between prosecutorial demands for strong sentencing practices and the social and legal transitions occurring with respect to cannabis in the index period:

In my view, the Crown's 'get tough' approach runs afoul of Parliament's intentions as set out in the Criminal Code that custodial sentences should be dispensed with caution and that an accused should not be deprived of his liberty where less restrictive sanctions are available (R. v. Smith [1997]).

Further, there is evidence that the cannabis debate effects the decision making processes of judges. This is exemplified by a judge who acknowledges cannabis' status as a debated 
substance and acknowledges the legal medicinal aspect of cannabis as well as the efforts of those activists arguing for decriminalization:

There is a debate in Canada, as well as in the US at the present time, a debate ongoing as to the medical benefits of cannabis in its crude from. This debate has been carried into the courts in a number of drug prosecutions in Canada in recent years. Current writings on the subject show that the Government of Canada is at the present time being petitioned by some individuals to create an exemption as provided for under the Controlled Drugs and Substances Act, to allow for the legal dispensing of cannabis marihuana in its crude form (R. v. Krieger [1998]).

While this last remark makes no positive or negative response to cannabis offenders, it does indicate that the debate has been involved in the assessment of cannabis offences in Canada. Another good example is given in R. v. Malmo-Levine [2002], where the consequences of the debate are mentioned and the necessity for Parliament's response is noted:

We agree that the effects on an accused person of the criminalization of marihuana possession are serious. They are the legitimate subject of public controversy. They will undoubtedly be addressed in parliamentary debate $(R$ v. Malmo-Levine [2002]).

These remarks provide a richer understanding of divergent responses to cannabis in the judiciary and, reinforced by the quantitative analysis, help to show that there may be divergent sentencing practices as well.

The findings from the qualitative data analysis related to cannabis sentencing practices suggest that while cannabis is a contested topic in Canadian society, it is also a contested topic within the judiciary. The evidence suggests that cannabis, and narcotics offences in general, are not responded to uniformly by the judiciary. Further, judges hold a variety of opinions regarding how to respond to cannabis offences. Importantly, there is a distinct disjuncture between the legislation's recommended sentencing maximums and 
the actual sentencing practices of the judiciary with respect to cannabis; there is no consistency in the sentencing of cannabis offenders given the sentencing maximums provided by Parliament. 


\section{CHAPTER 7: Conclusions and Recommendations}

Judging from academic research, governmental inquiries, and news media reports, cannabis is the focus of a heated debate in Canadian society. While some feel that cannabis is necessarily illegal and that its use violates the shared obligations Canadians have constructed to maintain equitable and repeatable social relations, others argue that cannabis is not a dangerous drug and its use should not be illegal. Regardless of which side of the debate people are on, there is no consensus regarding how to deal with cannabis use.

This research focused on the practices of a subset of the Canadian population, the judiciary, and has provided a glimpse into its varying responses to cannabis. The research has examined sentencing practices in cannabis, and other narcotics cases as well, to produce an analysis of the types of responses that the judiciary has to various cannabis cases. The examples presented above show no uniformity of view regarding cannabis and cannabis offences among the judiciary. This finding is supported by statements drawn from judicial decisions which reflect varied opinions regarding cannabis and cannabis sentences. Some judges agree that cannabis is a social problem that contributes to the existence of criminal behaviour in Canadian society. Other judges treat cannabis offenders less severely, noting Canadian morals and values are changing and that our legal definitions may someday also change. However, judges on either side of the discussion agree that the law stands as written and that it is not for the judiciary to engage in lawmaking. Rather, it is the role of the judiciary to uphold the law, though it is capable of recommending where change may be needed. Further, it is the role of the judiciary to 
uphold the Canadian Charter of Rights and Freedoms which guarantees the rights of citizens to fair trial and fair prosecution. While many cases address the Charter, this study does not; however, further research may yield a discrepancy between responses in cases where the Charter is involved and those where the accused does not claim the Charter was violated.

These findings point to the diversity of perception in the collective consciousness of our judiciary; while there are divergent opinions regarding a specific issue, all are bound to follow the letter of law since it is through the rule of law that solidarity and social cohesion are maintained. Thus, while judges do respond differently from one another in sentencing and in statement, they are bound by their collective responsibility to uphold existing laws until these laws are either transformed or repealed.

Several recommendations can made regarding future research in this area. First, a detailed history of the evolution of cannabis as a social substance and as a narcotic would have helped to explain what cannabis is and why its use is contested. Second, looking at the quantitative analysis, a more detailed data set would have provided the possibility of a more elaborate picture of sentencing practices. This detail would have required requesting more specific data on the types of offences, and the specific lengths or amounts of the punishment awarded; a numeric analysis of sentencing length would have allowed for a stronger statistical analysis to be completed. Third, while the qualitative case review provides context regarding sentencing decisions, it does not provide an opportunity to discuss the issues directly with judges. Developing a semi-structured interview guide, centred on the topic of cannabis in the courts and in Canadian society, would provide more detailed information on the issues addressed in this research project 
as well as the unique reflections of those who have been involved in sentencing cannabis offenders. While these recommendations would have provided a more in depth and detailed analysis, the methodology used in this study was able to provide important insights into sentencing in cannabis cases and to warrant further research in this area. This study is a pilot study into an important area in Canadian society. The findings show that cannabis cases elicit complex responses from Canada's judges; the verbal responses found are neither uniform nor on one side of the cannabis debate. Second, the research shows that there are diverse sentencing practices with respect to cannabis offences. This suggests that while maximums and sentence types do exist which recommend the type of sentences legislators find most appropriate, Canada's judiciary is reflective and creative when sentencing cannabis offenders. This demonstrates the discretionary power of judges in our criminal court system. Further, the research shows that regardless of the media attention and law enforcement rhetoric associated with cannabis offences, slightly more than fifty percent of cannabis offenders are successfully prosecuted. At the same time, criminal justice and law enforcement officials continue to demand enforcement and prosecution tax dollars for a drug war which, in the courts, sees as many acquittals and dismissals as it does convictions.

Finally, with respect to the functional theory discussed earlier, it should come as no surprise that in a highly developed and complex society, all individuals are capable of holding differing opinions while still consenting to the rule of law. Judges show a variety of sentencing practices with respect to cannabis. However, these diverse sentencing responses are very similar to the responses given for all other narcotics offences in Canada, suggesting that the responses of judges to drugs in general are divergent. Further, 
they are divergent with the views of Parliament with respect to the sentencing of cannabis offenders, showing, more often than not, that judges are willing to sentence all drug offenders more leniently than the legislative assembly would like. These findings reinforce the argument that legal, moral, and social debates are prominent even in the courts which uphold and regulate the laws our society collectively develops. Regardless of its role, the judiciary is prone to subjective moral differentiation like any other social group in society. While no concrete answer can be given to what opinion's judges may personally hold, the evidence presented in this thesis shows that judges are active in the cannabis debate through their sentencing practices.

Cannabis will be debated for many years in Canada. Looking to those individuals whose duty it is to react to legal and moral transgressions may be a good method for determining when specific legal definitions are no longer as concrete as they once were. Cannabis is a substance over which there is considerable debate including questions of common moralities, the validity of laws, and the strength of social cohesion; perhaps the responses of the judiciary may be a litmus test for citizens and politicians alike for determining when changes are in order for our laws, attitudes, and perceptions. Acknowledging when specific laws are outdated or ill-designed for the society of which they regulate represents part of the broader processes of social change. These processes involve many actors in society and help to create solidarity among social actors differentiated by background, creed, and belief. They also help to create consensus among groups who would otherwise be antagonistic. Our responsive judiciary, an institution which has contributed to social change before, is an institution where 
collective sentiments can be translated into socially transformative judgements, which can then shape and transform the common morality of Canada and its citizens. 


\section{APPENDIX I: BIBLIOGRAPHY}

Alpert, J. (1982). Exercising Discretion on the Bench: The Trial Judge's Perspective. In B. Atkins and M. Pogrebin (Eds.), The Invisible Justice System (pp. 93-104). Cincinnati: Anderson P.C.

Atherton, T.J. (Date Unknown). "Managing Police Discretion." Retrieved June 12 2007: http://www.nceta.flinders.edu.au/pdf/proceedings2001/atherton.pdf

Benoit, E. (2003). "Not Just a Matter of Criminal Justice: States, Institutions, and North American Drug Policy." Sociological Forum, 18(2), pp. 269-293.

Ben-Yehuda, N. (2006). Contextualizing Deviance Within Social Change and Stability, Morality, and Power. Sociological Spectrum, 26, pp. 559-580.

Bill C-38, An Act to amend the Contraventions Act and the Controlled Drugs and Substances Act, 2d sess. Parliament, 2002-2003.

Bittner, E. (1979). The Functions of the Police in Modern Society: A review of background factors, current practices, and possible role models. Cambridge, Mass.: Oelgeschlager, Gunn and Hain.

Boucock, C. (2000). In the Grip of Freedom: Law and Modernity in Max Weber. Toronto: University of Toronto Press.

Boyd, N. (1998). Rethinking our policy on cannabis. Policy Options, pp. 31-33.

Brauti, P.M., and Puddington, B.G. (2003). Prosecuting and Defending Drug Offences. Aurora, Ontario: Canadian Law Books Incorporated.

CTV (2007). "Hotline launched to combat marijuana grow-ops." Retrieved February 10 2007:

http://toronto.ctv.ca/servlet/an/local/CTVNews/20070201/grow_op hotline 070201?hub $=$ TorontoHome

Canada.(1972). Commission of Inquiry into the Non-Medical Use of drugs. Cannabis: Report of the Commission of Inquiry into the Non-Medical Use of Drugs. Chair: Gerald LeDain, Ottawa: Information Canada.

Canada. (2003). Parliament, House of Commons. Debates, $37^{\text {th }}$ Parliament, $2^{\text {nd }}$ Session, 2003, vol. 138, No. 137, October 9, 2003. Ottawa: Canadian Government Publishing, 2003.

Canadian Association of Police Boards (CAPB). (2005). Report on 2005 Consultation with Federal Ministers and Fourth Annual Joint Meeting with CACP and CPPA. Retrieved February 27 2007: http://www.capb.ca/services/bulletins/bull85.shtml 
Canadian Centre for Justice Statistics (CCJS). Illicit Drugs and Crime in Canada. February 1999. Ottawa: Statistics Canada.

Canadian Centre for Justice Statistics Policing Services Program. Uniform Crime Reporting Incident-Based Survey: Reporting Manual. March 2006. Ottawa: Statistics Canada.

Canadian Criminal Justice Association (CCJA). Parliament. House of Commons. Standing Committee on Justice, Human Rights, Public Safety and Emergency Preparedness. On Amendments to the Criminal Code of Canada (minimum penalties for offences involving firearms) Bill C-10. $39^{\text {th }}$ Parliament, $1^{\text {st }}$ Session, October $31^{\text {st }} 2006$.

CBC. (2002). "Senate pot report leaves police fuming". Retrieved June 202007 : http://www.cbc.ca/canada/story/2002/09/05/pot senate020905.html

CBC (2002 (2)). "Harper slams Senate pot report". Retrieved June 6 2007: http://www.cbc.ca/canada/story/2002/09/05/pot harper020905.html

CBC (2004). “Liberals Reintroduce Marijuana Bill". Retrieved July 62007 . http://www.cbc.ca/canada/story/2004/11/01/marijuana_billo41101.html

CBC (2007). “In Depth: The Drug Trade." Retrieved July 62007 : http://www.cbc.ca/news/background/drugs/users.html

Cotterrell, R. (1992). The Sociology of Law: An Introduction ( $2^{\text {nd }}$ Edition). London: Butterworths.

Criminal Intelligence Directorate (CID). (2005). Strategic Intelligence Assessment: Drug Situation in Canada 2004. RCMP, Major and Organized Crime Intelligence Branch: Regina.

Crutcher, N. and Gabor, T. (2001). Mandatory Minimum Penalties: Their effects on crime, sentencing disparities, and justice system expenditures. Department of Justice, Research and Statistics Division, Government of Canada: Ottawa.

Culliton, E.M. (1980). Sentencing Guidelines: A Judicial Viewpoint. In B. Grosman (Ed.), New Directions in Sentencing. Toronto: Buttersworth.

Davis, K.C. (1975). Police Discretion. St. Paul: West Publishing Company.

Davies, C.A. (1999). Reflexive Ethnography. London: Routledge.

De Gaay Fortman, B. (2006). Adventurous Judgements: A comparative exploration into human rights as a moral-political force in judicial law development. Utrecht Law Review. 2(2), pp.22-44. 
Durkheim, E. (1982). The Rules of the Sociological Method and Selected Texts on Sociology and its Method. Toronto: The Free Press.

Durkheim, E. (1984). The Division of Labour in Society. New York: The Free Press.

Dworkin, R.M. (2006). Justice in Robes. Cambridge, MA: Belknap Press.

Erickson, P.G. (1980). Cannabis Criminals: the social effects of punishment on drug users. Toronto: Addiction Research Foundation.

Erickson, P.G. and Oscapella E. (1999). Cannabis in Canada - a puzzling policy. International Journal of Drug Policy, 10(4), pp. 313-318.

Fife, R. (1999) Police chiefs get through to the top. The National Post. Retrieved June 9 2007: http://www.cfdp.ca/natpost.htm

Finckenauer, J. (1982) Some Factors in Police Discretion and Decision Making. In B. Atkins and M. Pogrebin (Eds.), The Invisible Justice System (pp. 43-56).

Cincinnati: Anderson P.C.

Galligan, D.J. (1986). Discretionary Powers: A legal study of official discretion. Oxford: Clarendon Press.

Gardner, D. "The police aren't Experts on drug use." Ottawa Citizen, July 13 2007, p. A13.

Gardner, Dan. (10 Mar 2004). "Straight Dope on Police Scare Tactics." The Edmonton Journal. Retrieved June 11 2007:

http://www.mapinc.org/drugnews/v04/n416/a05.html?64994

Garland, D. (2001). The Culture of Control: crime and social order in contemporary society. Chicago: University of Chicago Press.

Giffen, P.J., Endicott, S.J., and Boorman, S. (1991). Panic and Indifference: the politics of Canada's drug laws: a study in the sociology of law. Ottawa: Canadian Centre on Substance Abuse.

Goldstein, J. (1982). Police Discretion Not to Invoke the Criminal Process. In B. Atkins and M. Pogrebin (Eds.), The Invisible Justice System (pp. 33-43). Cincinnati: Anderson P.C.

Golub, A and Johnson, B.D. (2002). The misuse of the 'Gateway Theory' in US policy on drug abuse control: A secondary analysis of the muddled detection. International Journal of Drug Policy, 13, pp. 5-19. 
Hall, S. (1978). Policing the Crisis: Mugging, the State, and Law and Order. New York: Holmes and Meier.

Hall, W. and Solwij, N. (1998). Adverse effects of cannabis. Lancet, 352, pp.1611-1616.

Health Canada (2005). Information for Health Care Professionals-Clinical Pharmacology. Retrieved May 13 2007:

http://www.hc-sc.gc.ca/dhp-mps/marihuana/howcomment/medpract/infoprof/clinicalclinique e.html

Health Canada. (2005(2)) Frequently Asked Questions- Medical Use of Marijuana. Retrieved April 15 2007:

http:/www.hc-sc.gc.ca/dhp-mps/marihuana/about-apropos/faq_e.html

Healey, J.F. (2001). Statistics: A Tool for Social Research. London: Thompson Learning.

Himma, K.E. (1999). Judicial Discretion and the Concept of Law. Oxford Journal of Legal Studies, 19, pp. 71-82.

Hoffman, P.B. and DeGostin, L.K. (1975). An argument for self-imposed explicit judicial sentencing standards. Journal of Criminal Justice, 3, pp. 195-206.

Hollister, L.E. (2000). An approach to the medical marijuana controversy. Drug and Alcohol Dependence, 58, pp. 3-7.

Homel, R (1986). Policing and punishing the drink driver: a study of general and specific deterrence. New York: Springer-Verlag.

Iversen, L. (2004). Cannabis and the law - high time for reform? European Review, 12(4), pp. 513-525.

Javed, N. (2007). "Experts urge Ottawa to fix marijuana laws." Retrieved July 282007 : http://www.medicalmarihuana.ca/experts.html

Jones, S.J. (2001). Durkheim Reconsidered. Oxford: Blackwell Publishers Ltd.

Kenny, C. and Nolin, P.C. (2003). Cannabis: Senate Special Committee on Illegal Drugs. Toronto: University of Toronto Press.

Khoo, L. (2001) Up in Smoke? Canada's marijuana law and the debate over decriminalization. CBC News Online. Retrieved May 13 2007:

http://www.cbc.ca/news/background/marijuana/marijuana legalize.html

Kisely, S. (2005). A tale of two jurisdictions: Can Australia and Canada learn from each other's experience with cannabis control? Australian and New Zealand Journal of Psychiatry, 39, pp. 154-160. 
Lacey, N. (1992). The Jurisprudence of Discretion. In K. Hawkins (Ed.) The Uses of Discretion, (pp. 361-389). Oxford: Clarendon Press.

Law, J. (2004). After Method: mess in social science research. New York: Routledge.

Lexum (Date Unknown). "Controlled Drugs and Substances Act", Federation of Law Societies of Canada, Retrieved September 11 2007:

http://www.canlii.org/ca/sta/c-38.8/

Lundman, R. (1980). Police Behaviour: A Sociological Perspective. NY: Oxford Press.

MADD (2003). Decriminalizing Cannabis -"They've got the cart before the horse." Retrieved May 25 2007:

http://www.madd.ca/english/news/pr/p030513.htm

MADD (2005). "MADD Canada Launches New Drug Impaired Driving Awareness Campaign Aimed at Youth and Post-Secondary Students." Retrieved May 25 2007: http://www.madd.ca/english/news/pr/p05aug29.htm

MedicalMarihuana (2001). "Health Questions." Retrieved February 202007 : http://www.medicalmarihuana.ca/healthquestions.html

Macdonald, S. and Erickson, P. (1999). Factors associated with attitudes toward harm reduction among judges in Ontario, Canada. International Journal of Drug Policy. 10 (1), pp. 17-24.

Macdonald, S., Erickson, P. and Allen, B. (1999). Judicial attitudes in assault cases involving alcohol or other drugs. Journal of Criminal Justice. 27(3), pp.275-286.

Miceli, T.J. and Cosgel, M.M. (1994). Reputation and judicial decision-making. Journal of Economic Behaviour and Organization, 23, pp. 31-51.

Mikuriya, T. (2004). Folk medicine/herbal remedies: Cannabis a unique analgesic. Journal of Pain, 5(3), pp. s52.

Miller, L. (2000). Smoked Out: What do Cops Really Think of Marijuana? Cannabis News. Retrieved June 24 2007:

http://cannabisnews.com/news/5/thread5596.shtml

Miller, J.L. and Sloan, J.J. III. (1994). A Study of Criminal Justice Discretion. Journal of Criminal Justice, 22(2), pp. 107-123.

Mills, C.W. (1959). The Sociological Imagination. Oxford: Oxford University Press. 
Murdock, D. (2002). Wasted Resources. National Review Online. Retrieved July 2 2007: http://www.nationalreview.com/murdock/murdock073002.asp

Nsereko, D.D.N. (1999). Minimum sentences and their effect on judicial discretion. Crime, Law, \& Social Change, 31, pp. 363-384.

O'Neill, J. (2007). Canadians among highest in world pot use. Retrieved July 112007 : http://www.canada.com/ottawacitizen/news/story.html? id $=688 \mathrm{c} 8943-\mathrm{c} 48 \mathrm{f}-4 \mathrm{ef} 8-\mathrm{b} 773$ dle $968976 \mathrm{cal}$ andk $=12968$

Ontario Association of Police Chiefs (OACP). (2002). OACP Drug Policy. Retrieved June 12 2007:

http://www.oacp.on.ca/uploads/pdfs/2002DrugPolicy.pdf

Parkin, F. (1986). Max Weber. London: Routledge.

Pridemore, W.A., Kim, S.A. (2007). Socioeconomic change and homicide in a transitional society. The Sociological Quarterly. 48, pp.229-251.

Pryce, G. and Baker, D. (2005). Emerging properties of cannabinoid medicines in management of multiple sclerosis. TRENDS in Neurosciences, 28(5), pp. 272-276.

Quann, N. (2003). Drug Use and Offending. Department of Justice, Research and Statistics Division, Government of Canada.

Quantitative Methods in Social Sciences (QMSS). (2003). Samples and Sampling. Retrieved June 11 2007:

http://ccnmtl.columbia.edu/projects/qmss/samp type.html

Reagan, R. September 14 1986. National Campaign against drug abuse: Address to the Nation. Weekly Compilation of Presidential Documents, 22 (38), pp. 1183-87.

REAL (Date Unknown). Marijuana is Bad News. Retrieved July 62007. http://www.realwomenca.com/newsletter/2000 Nov Dec/article 13.html

Reinerman, C. and Levine, H.G. (1997). Crack in America: Demon Drugs and Social Justice. Berkeley: University of California Press.

Roberts, J., and Cole, D.P. (1999). Introduction to Sentencing and Parole. In J. Roberts and D.P. Cole (Eds.), Making Sense of Sentencing (pp.3-31). Toronto: University of Toronto Press. 
Role of the Crown: Preamble to the Crown Policy Manual. Date Unknown. Retrieved 8 January 2008 :

http://72.14.205.104/search?q=cache:bTsXyXuGReUJ:www.attorneygeneral.jus.gov.on.c a/english $/ \mathrm{crim} / \mathrm{cpm} / 2005 / \mathrm{CPMPreamble} . \mathrm{pdf}+$ canadian+prosecutorial +discretion \&hl=en\& $\mathrm{ct}=\mathrm{clnk} \& \mathrm{~cd}=8 \& \mathrm{gl}=\mathrm{ca} \& \mathrm{client}=$ firefox $-\mathrm{a}$

SAFER. (2007). Marijuana vs. Alcohol. Retrieved 20 February 2007: http://www saferchoice.org/content/view/24/32/

Schmaus, W. (2004). Rethinking Durkheim and His Tradition. Cambridge: Cambridge University Press.

Schulenberger, J. (2003). The Social Context of Police Discretion with Young Offenders: An Ecological Analysis. In Canadian Journal of Criminology and Criminal Justice, April, pp. 127-157.

Shafer, R., et al (1972). Marihuana: A Signal of Misunderstanding, Chap. V, Washington, DC: National Commissions on Marihuana and Drug Abuse.

Shiner, M. (2003). Out of harm's way? British Journal of Criminology, 43, pp. 772-796.

Soellner, R. (2005). Dependence on Cannabis - An Ever Lasting Issue. Substance Use \& Misuse, 40(6), pp.857-867.

STOPTHEDRUGWAR (2003). Canada Decriminalization Bill Dies Quiet Death. Retrieved 20 February 2007:

http://stopthedrugwar.org/chronicle-old/311/c38.shtml

Tarter, R.E., Vanyukov, M., Levent, L, Reynolds, M., and Clark D.B. (2006). Predictors of Marijuana Use in Adolescents Before and After Licit Drug Use: Examination of the Gateway Hypothesis, American Journal of Psychiatry, 63 (12), pp. 2134-2140.

Tata, C. (1998). The Application of Judicial Intelligence and 'Rules' to Systems Supporting Discretionary Judicial Decision-Making. Artificial Intelligence and Law, 6, pp. 203- 230 .

The White House. (2007). National Drug Control Strategy.

Trotter, G.T. (1999). Appellate Review of Sentencing Decisions. In J. Roberts and D.P. Cole (Eds.), Making Sense of Sentencing (pp. 230-242). Toronto: University of Toronto Press. 
Vago, S. and Nelson, A. (2008). Law and Society. Toronto: Prentice Hall.

Warburton, H., May, T. and Hough, M. (2005). Looking the Other Way. British Journal of Criminology, 45, pp. 113-128.

Ware, M.A., Doyle, C.R., Woods, R.W., Lynch, M.E., and Clark, A.J. (2003). Cannabis use for chronic non-cancer pain: results of a prospective survey. Pain, 102, pp. 211-216.

Willis, L.A., Coombs, D.W., Cockerham, W.C. and Frison S.L. (2002). Ready to die: a post-modern interpretation of the increase of African American adolescent male suicide. Social Science and Medicine, 55, pp.907-920.

Wilson, J. (1982). Police Discretion. In B. Atkins and M. Pogrebin (Eds.), The Invisible Justice System (pp. 53-69). Cincinnati: Anderson P.C. 
APPENDIX II: Cannabis cases drawn from LexisNexis ${ }^{\circledR}$

\begin{tabular}{|c|c|c|c|}
\hline \multicolumn{2}{|c|}{ CASE NAME } & YEAR & LOCATION \\
\hline Regina $v$. & Cyr & 1997 & Newfoundland \\
\hline Regina $v$. & O'Flaherty & 1997 & Newfoundland \\
\hline Regina $\mathrm{v}$. & Frennette & 1997 & Nova Scotia \\
\hline Regina $v$. & A.A.W. & 1997 & Ontario \\
\hline Regina v. & Gordon & 1997 & Saskatchewan \\
\hline Regina $v$. & Smith & 1997 & British Columbia \\
\hline Regina v. & Melvin & 1997 & Newfoundland \\
\hline Regina $\mathrm{v}$. & Galbraith & 1997 & Alberta \\
\hline Regina $v$. & Taylor & 1997 & Ontario \\
\hline Regina $v$. & Holder & 1998 & Ontario \\
\hline Regina $v$. & Krieger & 1998 & Alberta \\
\hline Regina $v$. & Cosgrove & 1998 & Newfoundland \\
\hline Regina $\mathrm{v}$. & Saunders & 1998 & Ontario \\
\hline Regina $v$. & Hackert & 1998 & Ontario \\
\hline Regina v. & St. George & 1998 & Ontario \\
\hline Regina $v$. & McDonnell & 1998 & Alberta \\
\hline Regina $v$. & Ross & 1998 & British Columbia \\
\hline Regina $v$. & Collins & 1999 & Newfoundland \\
\hline Regina $v$. & Hounjet & 1999 & Saskatchewan \\
\hline Regina $v$. & Wey & 1999 & Alberta \\
\hline Regina $\mathrm{v}$. & Hulan & 1999 & Newfoundland \\
\hline Regina $v$. & Walsh & 1999 & Newfoundland \\
\hline Regina $v$. & Neufeld & 1999 & Saskatchewan \\
\hline Regina v. & Downey & 1999 & Alberta \\
\hline Regina $\mathrm{v}$. & Auger & 2000 & Alberta \\
\hline Regina $v$. & Clay & 2000 & Ontario \\
\hline Regina $\mathrm{v}$. & Prussick & 2000 & Ontario \\
\hline Regina $v$. & Shacklock & 2000 & Nova Scotia \\
\hline Regina $v$. & Schweitzer & 2000 & Ontario \\
\hline Regina $v$. & Selby & 2000 & Quebec \\
\hline Regina v. & T.J.S. & 2001 & Saskatchewan \\
\hline Regina $v$. & Peterson & 2001 & British Columbia \\
\hline Regina $v$. & Connolly & 2001 & Newfoundland \\
\hline Regina $v$. & Jones & 2001 & British Columbia \\
\hline Regina $\mathrm{v}$. & Phan & 2002 & Saskatchewan \\
\hline Regina $v$. & McCurdy & 2002 & Nova Scotia \\
\hline Regina $\mathrm{v}$. & Patryluk & 2002 & Saskatchewan \\
\hline Regina $\mathrm{v}$. & Tobias & 2002 & Alberta \\
\hline Regina $v$. & $\mathrm{La}$ & 2002 & British Columbia \\
\hline Regina $v$. & Dean & 2002 & British Columbia \\
\hline Regina $v$. & Jones & 2002 & Nova Scotia \\
\hline Regina $v$. & Coulis & 2002 & Ontario \\
\hline Regina $v$. & Malmo-Levine & 2003 & Supreme Court \\
\hline Regina $v$. & Homby & 2003 & British Columbia \\
\hline Regina $\mathrm{v}$. & T.M. & 2003 & Saskatchewan \\
\hline Regina $\mathrm{v}$. & Reid & 2003 & PEI \\
\hline Regina $\mathrm{v}$. & Kozak & 2003 & Saskatchewan \\
\hline Regina $\mathrm{v}$. & Hannan & 2003 & Alberta \\
\hline Regina $v$. & Lambe & 2003 & Newfoundland \\
\hline Regina $\mathrm{v}$. & Bilton & 2003 & Ontario \\
\hline
\end{tabular}

Note. $\mathrm{n}=50$ 
APPENDIX III: Seriousness Rankings ${ }^{6}$

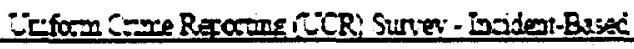

\subsection{SERIOLSIESS RDEX}

\section{Serionsmess Index}

incided:-basec UER Wolacoc Catics STJetize

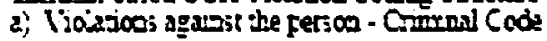

\section{Silohancoiss}

11:0

$11: 9$

11:3

1150

1163

$12: 0$

123

13:0

$15: 9$

1520

16:0

1609

163

$16: 9$

16.9)

1320

$1+i 0$

$1+53$

13ㄴำ

$1+30$

$1+40$

$1+7$

153

$15 \mathrm{~S}$

1560

$16: 5$

$11+3$

$1+3$

$1+63$

1540

1545

1340

$1+50$

$16: 9$

\section{$2 \sin$}

Murcer list Decee

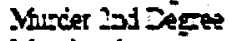

Mensingtos

Crimine Xegi:gence Cariogs Sent

Other Reinzed OEences Cxulino Deati

Aterotec Shizde

Consfiacy to Cocmer: Vurcier

Azqrazed Sexalal A isalt

Iistruppir

Fo:teg-ibice

Troscking in Froes

3obises:

Estarion

Exflosive; Cruing Deatio Bothy Binto

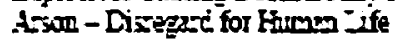

Oter Violstons agrins: to persoc

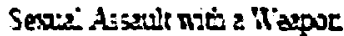

Argarated Asinul: - ieve! 3

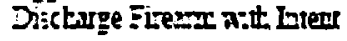

Sendis: As seult

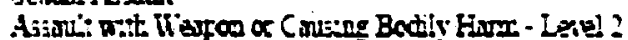
Tylantity C mise Botiy Hum

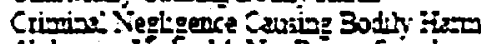

Abbictor lóser 14. Nox Paenr Giarcas

Abtrecoc lister 14. Contrering A Cuiwoty Ordx

Abtercor Linder 14. by Jarem Giardiar

Crimizi Hiras:ment

Infarcicide

Asiri:-Level :

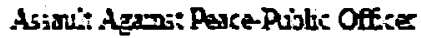

Ajtictioc Lisier 16

Berorie Ciitren F:om Caroda

Other Sesunl Crime;

Other A5s:ults

itterizg 7treats
Vaxpenit:

25 yet:

25 yen:

$\because=$ yeuri

:O yen:

5 years

Poge 36

\footnotetext{
${ }^{6}$ Taken from CCJS (2006) Uniform Crime Reporting Incident-Based Survey, pp.236-238
} 
b) Propery and Otte: Crimicn Coje Eedera: Sinures.

Prouncial Sizoures

Viojaror Coce

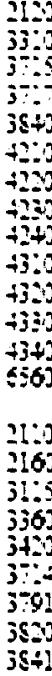

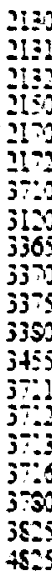

Dessexcong

Bresis mat Exter

Offersive iTier oci - Expiostes

irstrice or Cormisico of Ac: for Tetrorien

Ioss Ienonsx

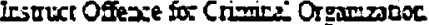

Trafiding - Heroin

Trastivas- Cocar

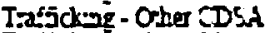

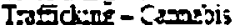

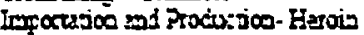

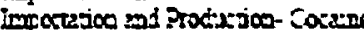

Imporasoon ent Prodivios. Otore CSSt

imforajoc-Camabs:

Iisuoci Defenie Ac:

Arom

Frave

In:po of the arails of proicizion of a persoc unde 18

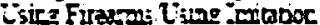

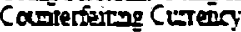

Faclete Tecarst Acis:ty

irciziciajoo Justice Syz:enr Doutc:

Offerce: Relatec :o Civerny

Coomir Offecce :0: Crixici: Orgarigacoc (Par. XII

C.C.)

Tast: O.e: 55,000

Taef of a molut velucis or.e $55.0 \%$

Taef: ort 55.00) foos 2 xo:s: : vive

Posileisar of S:0:20 Goot:

Yiscine:

Vistivef Ores: $: \hat{\mathrm{COC}}$

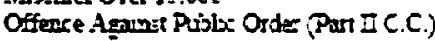

Procring

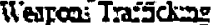

Posieisior Coctrany to Orser

Posieisioc of 11 zupus

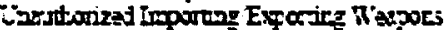

Distrtuios o: Coild Po.roगsaph

Property or Serice for Teguris: Acciny

Fresere of Propert. Disclostre. Auti:

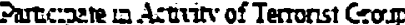

Eintorir or Cocceal Terorst

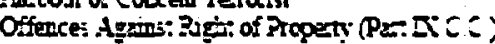

Procert: of 7 ine ( $C:$

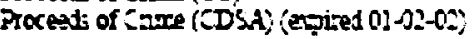

Vex Pensin:

35 years

:- yaurs

: syears 
APPENDIX IV: Frequency Distribution of Jurisdiction in Case-Law Review Jurisdiction of Offence in Case-Law Review

\begin{tabular}{|c|c|c|}
\hline & $\mathbf{n}$ & $\%$ \\
\hline Alberta & 8 & 16.0 \\
\hline British Columbia & 7 & 14.0 \\
\hline Newfoundland & 9 & 18.0 \\
\hline Nova Scotia & 4 & 8.0 \\
\hline Ontario & 11 & 22.0 \\
\hline PEI & 1 & 2.0 \\
\hline Quebec & 1 & 2.0 \\
\hline Saskatchewan & 8 & 16.0 \\
\hline Supreme Court & 1 & 2.0 \\
\hline Total & $\mathbf{5 0}$ & 100.0 \\
\hline
\end{tabular}




\section{APPENDIX V: Schedules II, VII, and VIII of the Controlled Drugs and Substances $\mathrm{Act}^{7}$}

SCHEDULE II

(Sections 2, 3, 4 to 7, 10,29, 55 and 60)

1. Cannabis, its preparations, derivatives and similar synthetic preparations, including

(1) Cannabis resin

(2) Cannabis (marihuana)

(3) Cannabidiol (2-[3-methyl-6-(1-methylethenyl)-2-cyclohexen-1-yl]-5-pentyl-1,3benzenediol)

(4) Cannabinol (3-n-amyl-6,6,9-trimethyl-6-dibenzopyran-1-ol)

(5) Nabilone (( \pm -trans-3-(1,1-dimethylheptyl)-6,6a, 7,8,10,10a-hexahydro-1-hydroxy-6,6dimethyl-9H-dibenzo[b,d]pyran-9-one)

(6) Pyrahexyl (3-n-hexyl-6,6,9-trimethyl-7,8,9, 10-tetrahydro-6-dibenzopyran-1-ol)

(7) Tetrahydrocannabinol (tetrahydro-6,6,9-trimethyl-3-pentyl-6H-dibenzo[b,d]pyran-1-ol)

(7.1) 3-(1,2-dimethylheptyl)-7,8,9,10-tetrahydro-6,6,9-trimethyl-6H-dibenzo[b,d]pyran-1-ol (DMHP)

but not including

(8) Non-viable Cannabis seed, with the exception of its derivatives

(9) Mature Cannabis stalks that do not include leaves, flowers, seeds or branches; and fiber derived from such stalks

1996, c. 19, Sch. II; SOR/98-157; SOR/2003-32, s. 1.

\footnotetext{
${ }^{7}$ From Lexum "Controlled Drugs and Substances Act", Federation of Law Societies of Canada, Retrieved September 11 2007:

http://www.canlii.org/ca/sta/c-38.8/
} 
SCHEDULE VII

(Sections 5 and 60)

Substance

1. Cannabis resin

2. Cannabis (marihuana)

\section{Amount}

$3 \mathrm{~kg}$

$3 \mathrm{~kg}$

SCHEDULE VIII

(Sections 4 and 60)

\section{Substance}

1. Cannabis resin

2. Cannabis (marihuana)

1996, c. 19, Sch. VIII; SOR/97-230, s. 16

\section{Amount \\ $1 \mathrm{~g}$ \\ $30 \mathrm{~g}$}

